\title{
التراث والأزياء في عادات وتقاليد الزواج في بلاد بنى شَهر
}

\author{
د. سهيلة حسن عبد الله المنتصر اليماني \\ أستاذ الملابس و النسيج المساعد \\ عميد كلية التربية للاقتصاد المنزلي بمكة المكرمة
}

مجلة بحوث التربية النوعية - جامعة المنصورة

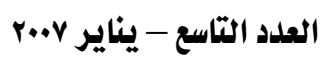




\section{التزاث والأزياء في عادات وتقاليد الزواج في بلاد بنى شهر}

د. سهيلة حسن عبد الله المنتصر اليماني

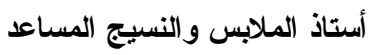

عميد كلية التربية للافتصاد المنزلي بككة المكرمة

المقدمة ومشكلة البحث :

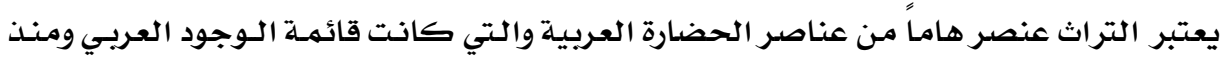

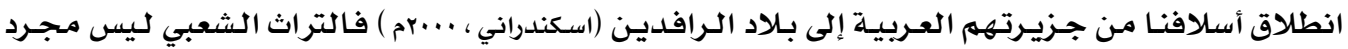

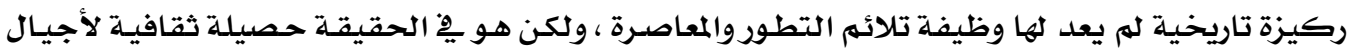

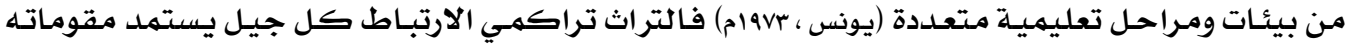

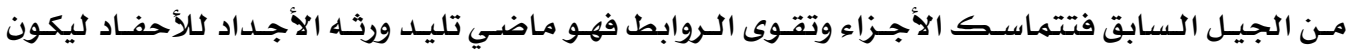

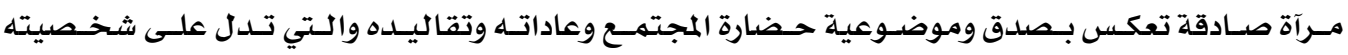

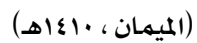

وتعتبر عادات وتقاليــ الـزواج مـن عناصـر الثقافـة التي تنتقل مـن جيل إلى آخـر والتي يـنقلها

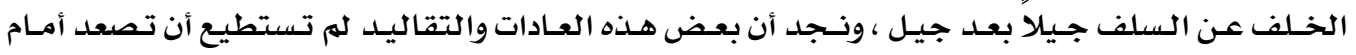

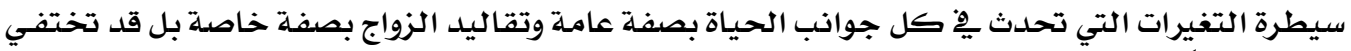
وتتخذ صورا جديدة .

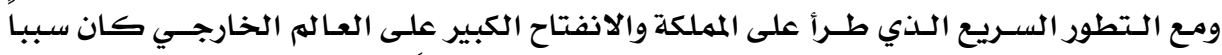

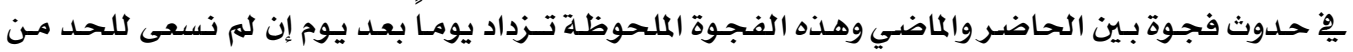

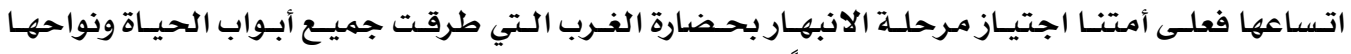

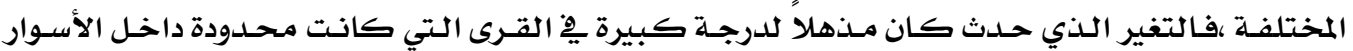
الكبيرة فامتدت وترامت أطرافها .

ولقد وضحت البسام ( 910ام ) مِّْ قولها "خوفاً من ضياع السمات التي تميز مجتمعنا السعودي

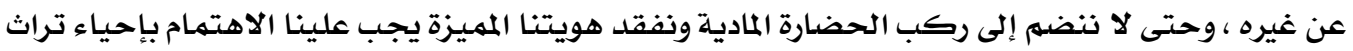

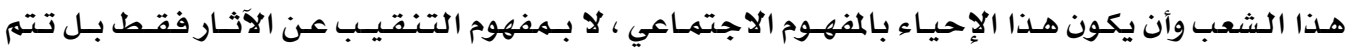

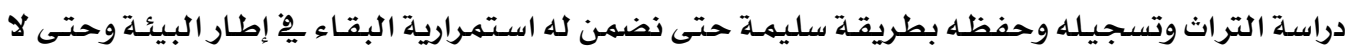

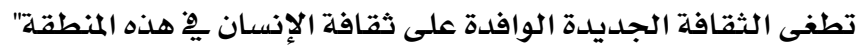

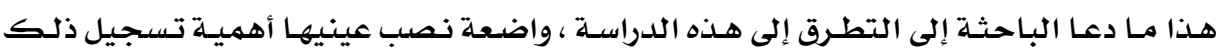

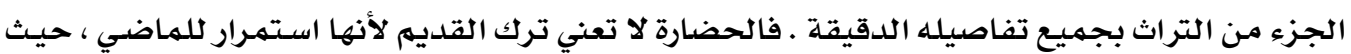

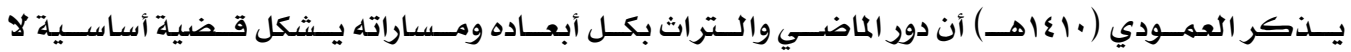

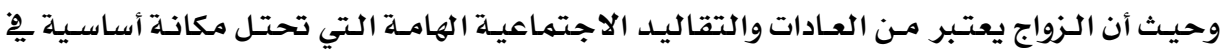

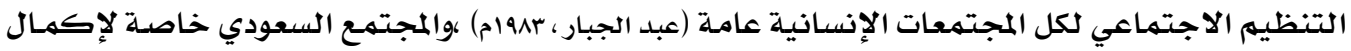

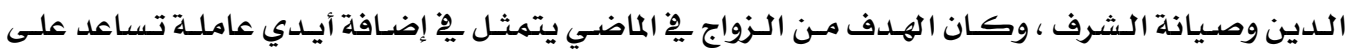


النشاط الاقتـــادي للأسـرة بإضـافة إلى مـا يـشكله الإنجـاب مـن هيبـة ومكانـة للأسـرة عـلاوة على القـوة

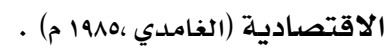

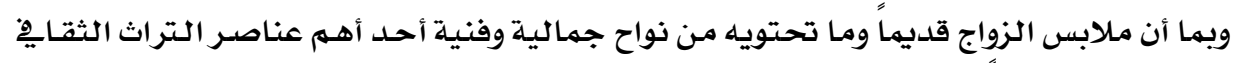

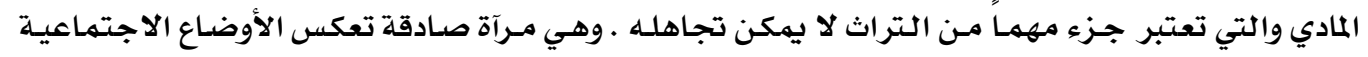

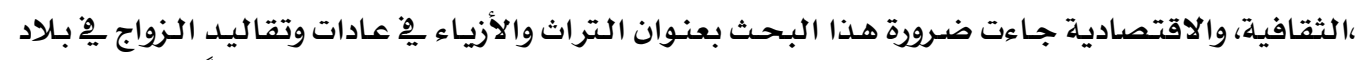

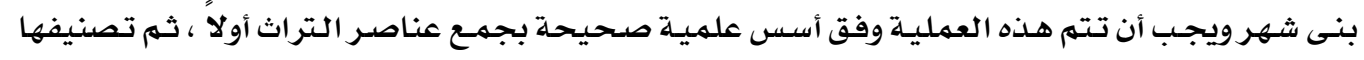

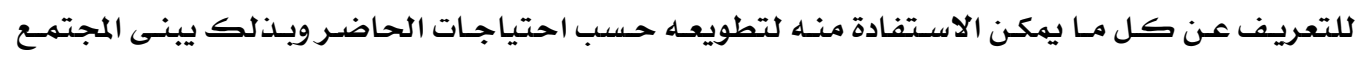

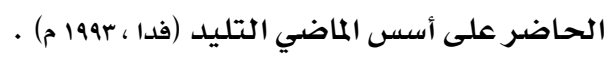
أهداف البـحث :

1- إلقاء الضوء على عادات وتقاليد الزواج عند أهالي المنطقة الجنوبية يِّ بـلاد بنى شهر •

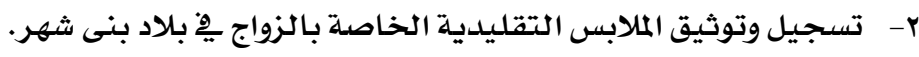

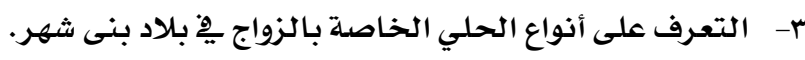

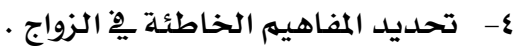
أهمية البحث :

1- الاستفادة من التراث التقليدي لقبائل بنى شهر بـاعتباره تاريخاً وحضارة .

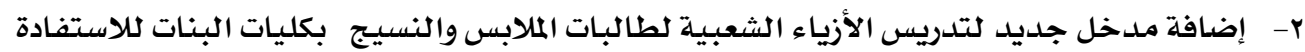

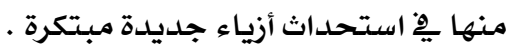
حدود البحث :

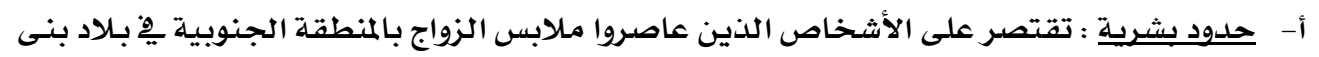

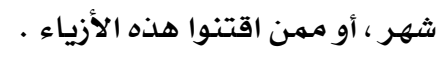

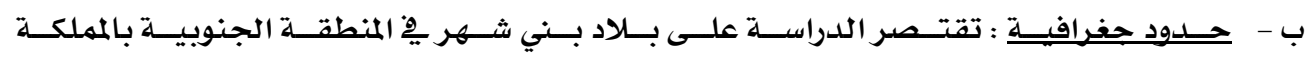
العربية السعودية.

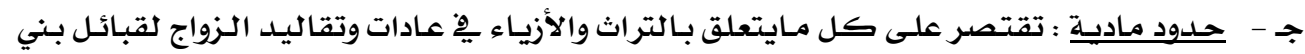

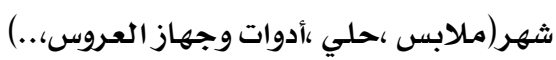
فروض البيحث :

ا- إمكانية تسجيل التراث التقليدي الخاص بعادات وتقاليد الزواج لقبيلة بني شهر.

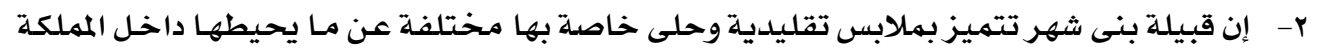
العربية السعودية.

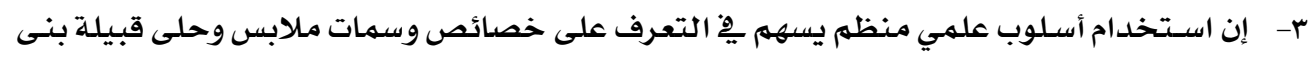
شهر وما تتميز به من تطريزوزخارف . 


$$
\text { منهج البحث : أبح: }
$$

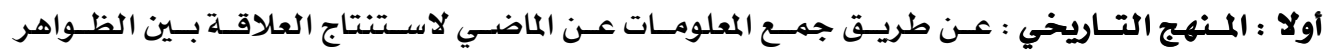

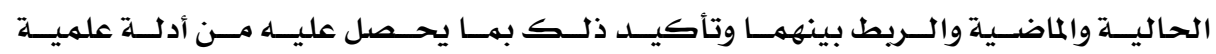

$$
\text { صحيحة (عبيدات وآخرون ، بوالهوام ) . }
$$

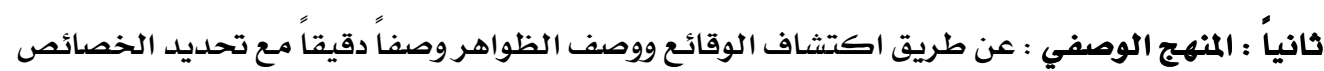

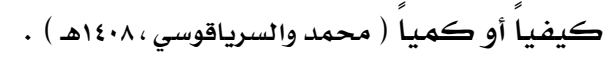

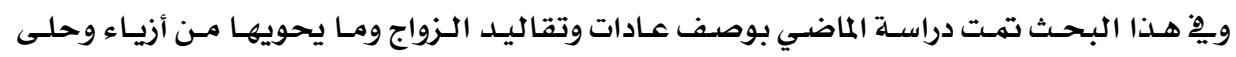

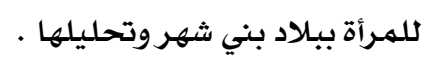

$$
\text { ع- - التصوير الفوتوغرايِّ. }
$$

$$
\begin{aligned}
& \text { 1- المقابلة الشخصية. } \\
& \text { r- التصوير بالماسح الضوئي. } \\
& \text { مصطلحات البحث : }
\end{aligned}
$$

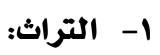

جاء ذكره بِّ القرآن بمعنى الميراث المنقول مـن الآبـاء إلى الأبنـاء قال تعالى : ( وتأكلون التراث

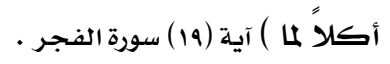

الإرث وأصله الورث ( البستاني ، به9ام ) ، وهو عناصر الثقافة التي تنتقل من جيل إلى آخر .

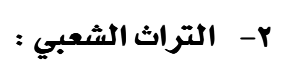

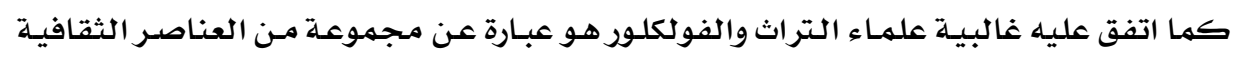

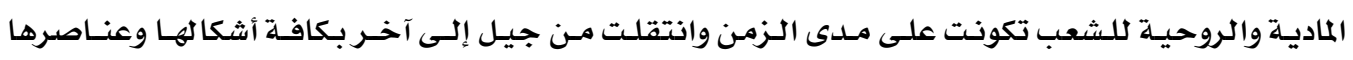

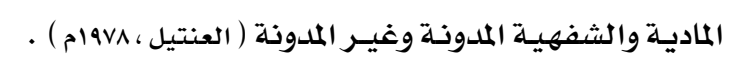

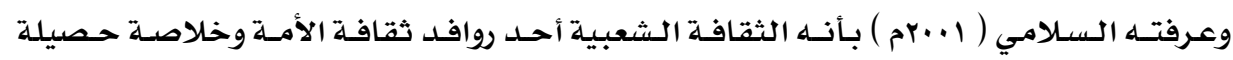

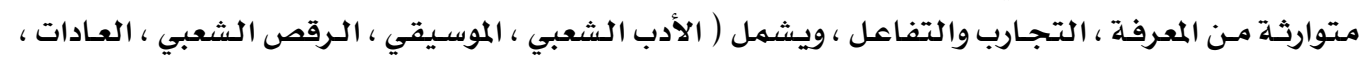

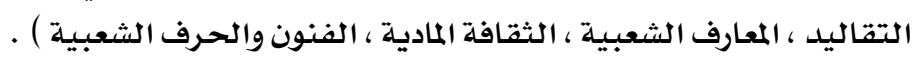

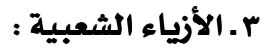

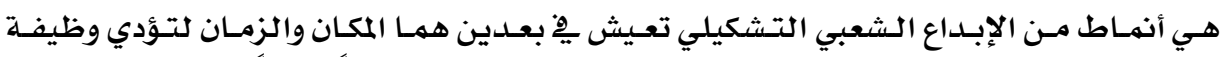

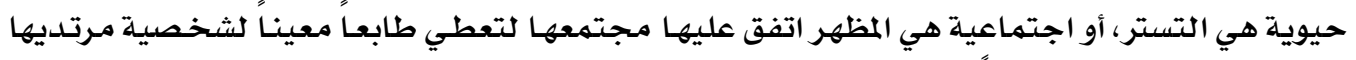

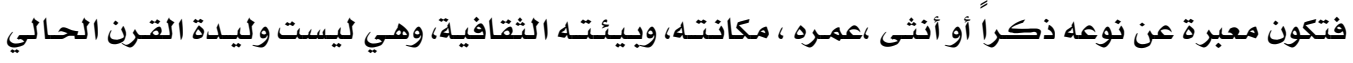

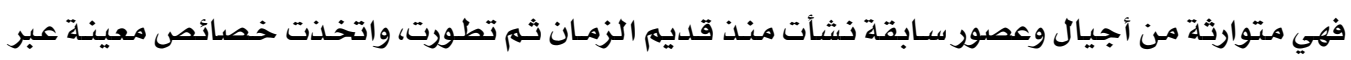
العصور التاريخية ( العمودي ، 1. أهارهـ ) .

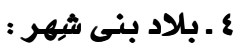

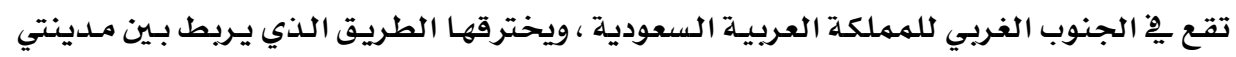

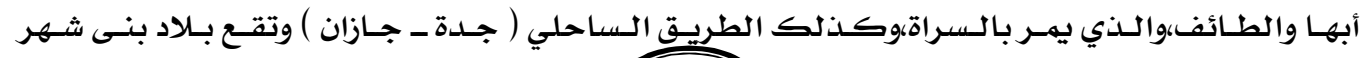




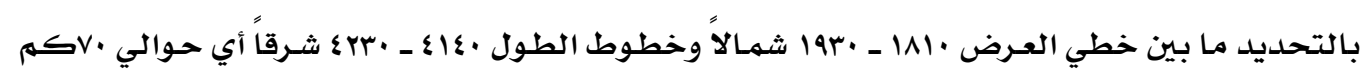

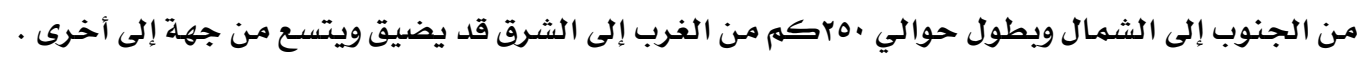

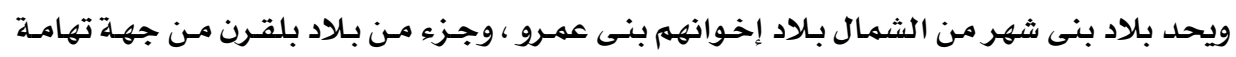

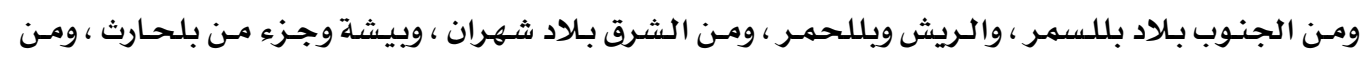

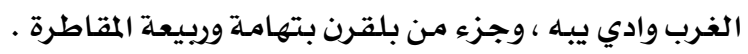
ويبلغ عدد سكان بني شهر حوالي مائتي ألف نسمة ـ ( الشهري ، 11ـاهـ ) .

ه ـ قبيلة بني شيهر :

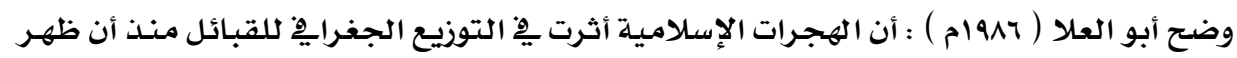

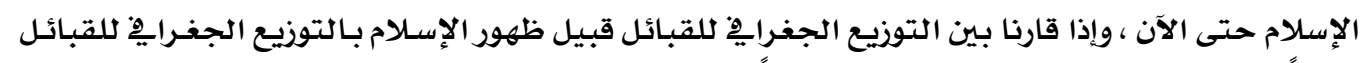

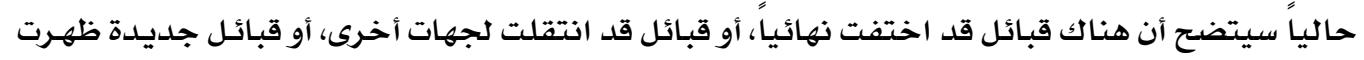
له تكن موجودة.

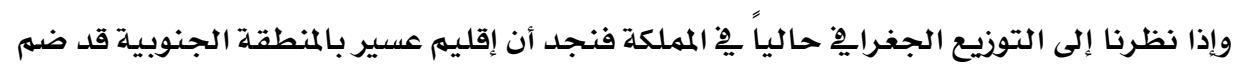
قبيلة بني شهر، وتنقسم قبيلة بنى شهر إلى فرعين حسب ما تعارف عليه السكان هما :

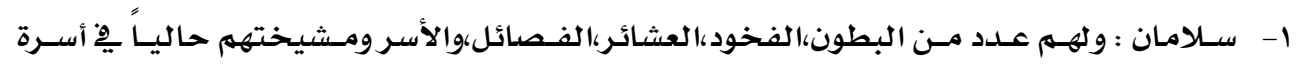

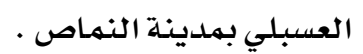

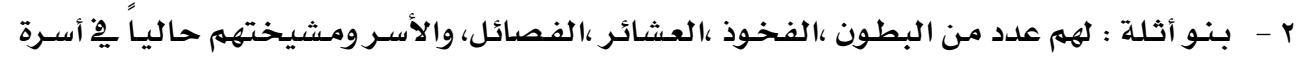

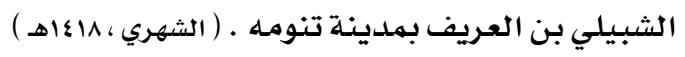

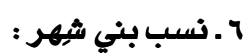

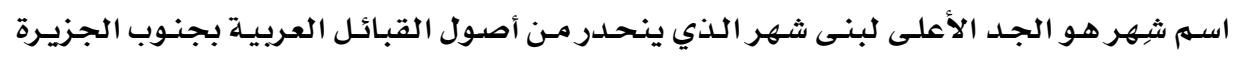

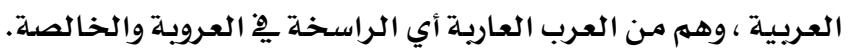

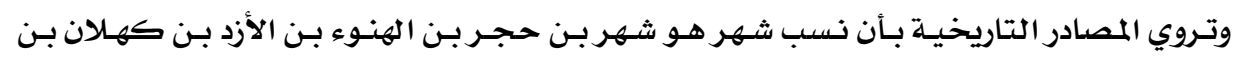
يشجب بن سباً بن يعرب بن قحطان بن هود علية السلام . V . العادات والتقاليد : ل هي أنهاط من الأفعـال،و السلوك، وسبـل التفكير تهثل طرق السـلوك الاجتمـاعي التي ارتضـاهـا

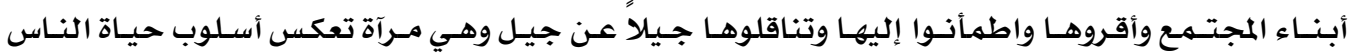

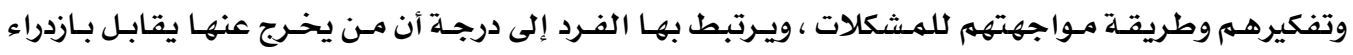

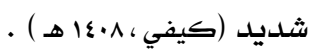

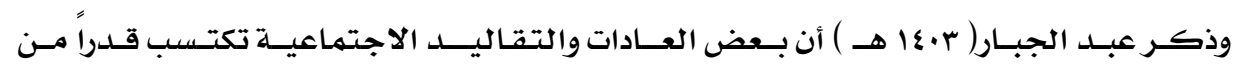

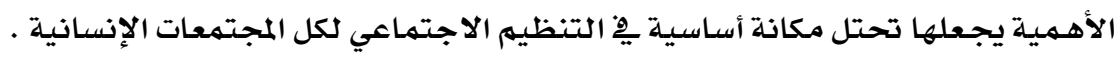
^. الزواج

$$
\text { عرف السنيدي ( •rعا هـ ) الزواج : }
$$

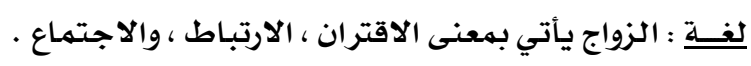




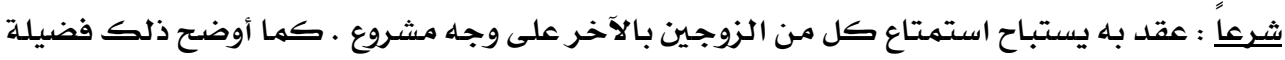

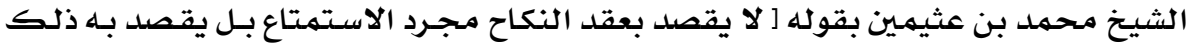

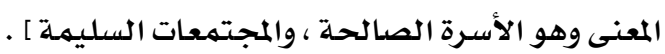

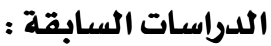

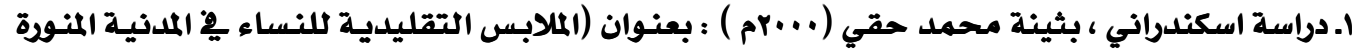

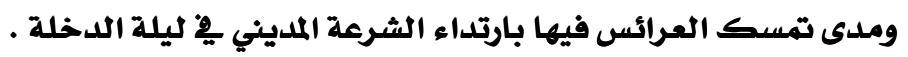

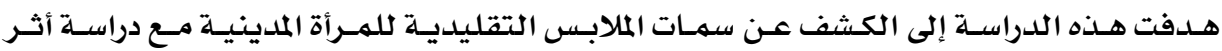

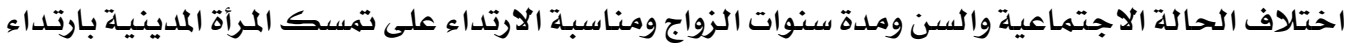

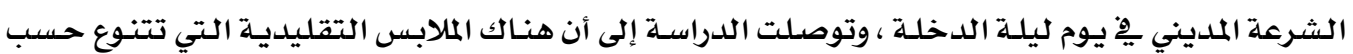

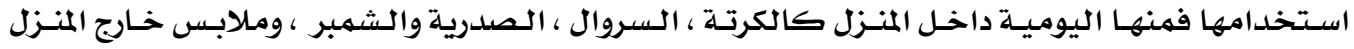

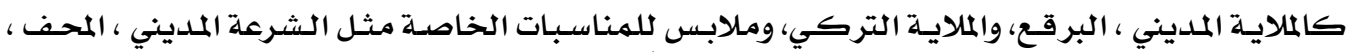

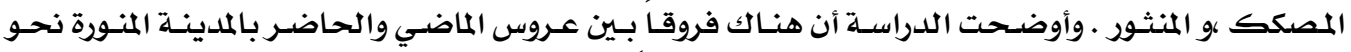

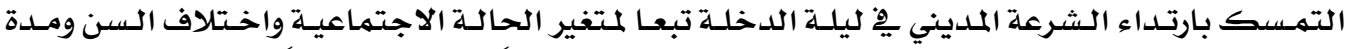

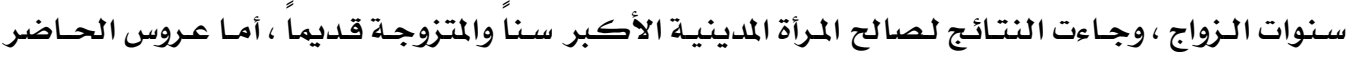

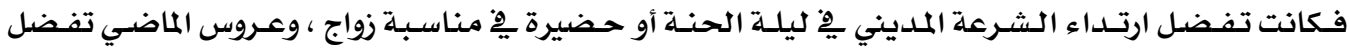

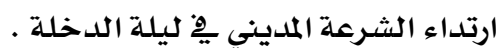

Y. دراسة البسام ، ليلى صالح (1910م ) : بعنوان (التراث التقليدي لملابس النساء مِّ نجد )

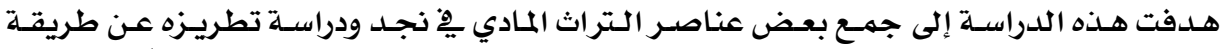

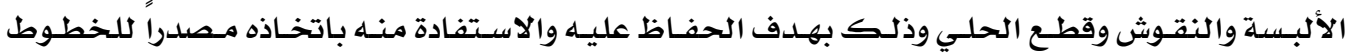

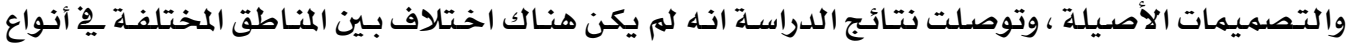

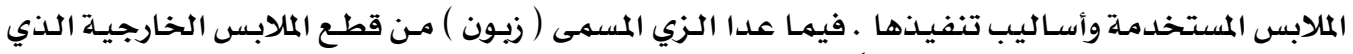

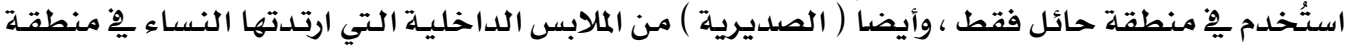

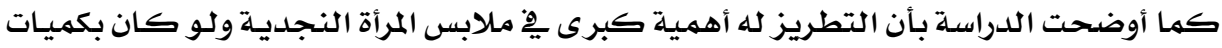

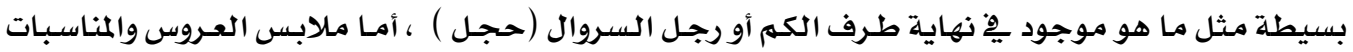

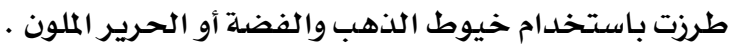

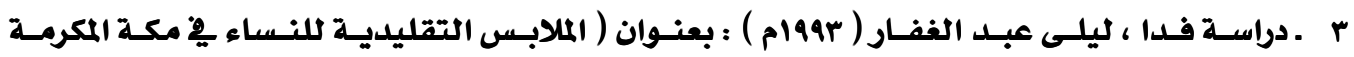

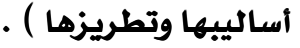

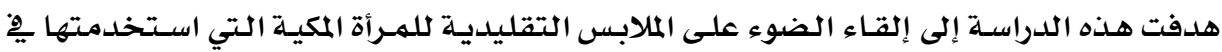

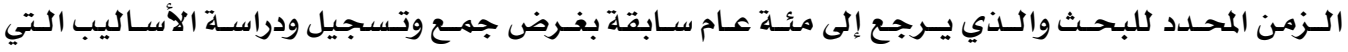

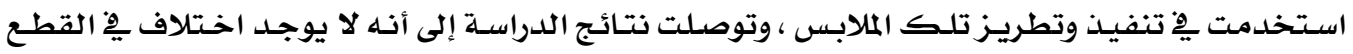

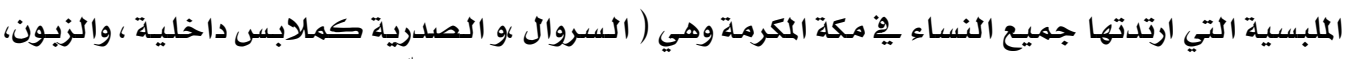

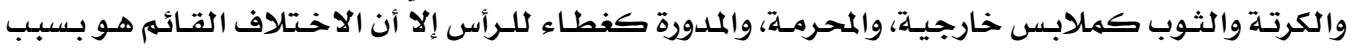




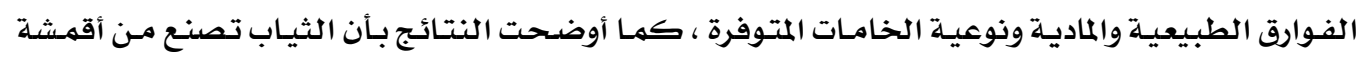

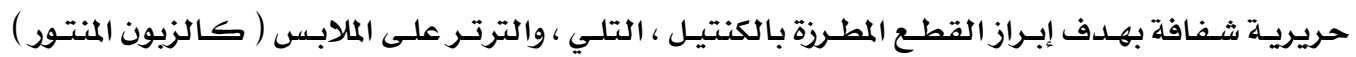

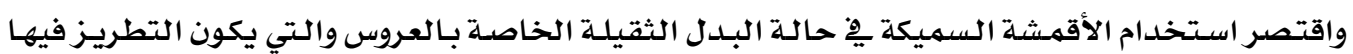

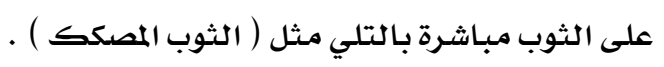

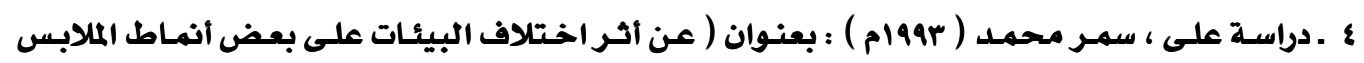
التراثية للنساء بِّ المملكة العربية السعودية ) ـ دراسة مقارنة.

هدفت الدراسة إلى توصيف الملابس بالبيئات المختلفة يو المنطقة الوسطى (الرياض ) والمنطقة

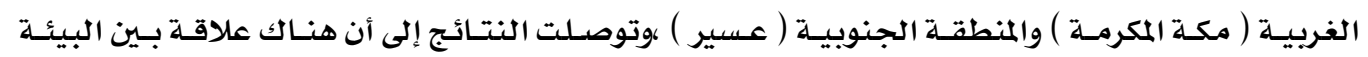

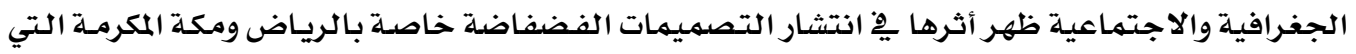

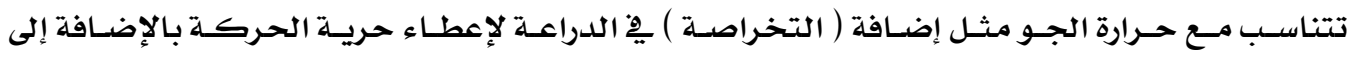

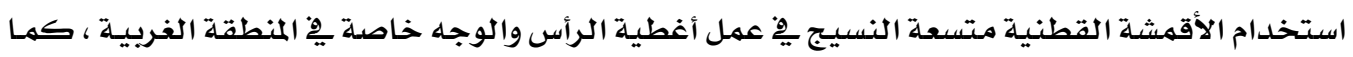

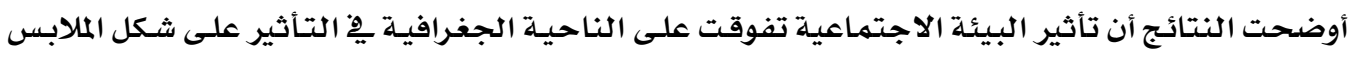

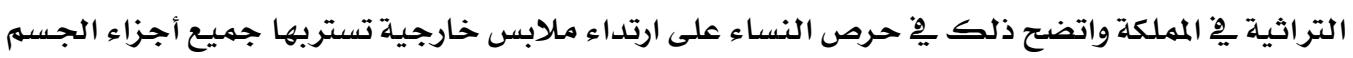

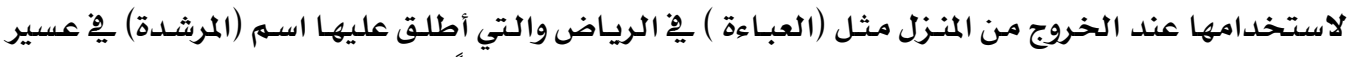

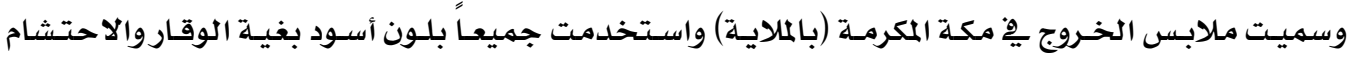

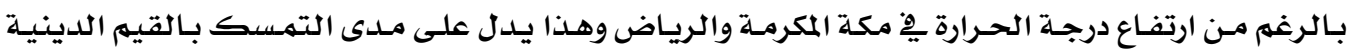

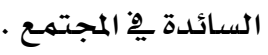

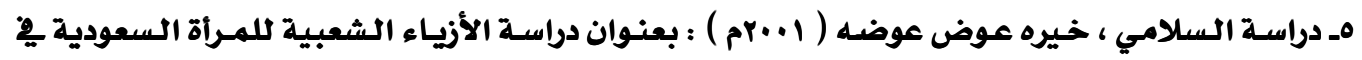
منطقة الباحة ماسلاسل

هدفت هذه الدراسـة إلى التعرف على الأنماط الملبسية للأزيـاء الشعبية للمـرأة ِِّ منطقة الباحسة

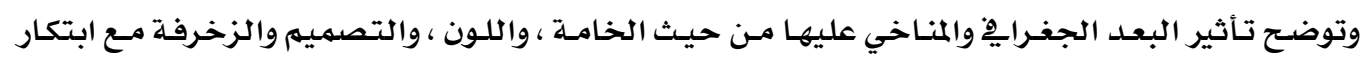

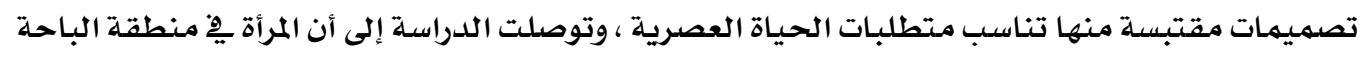

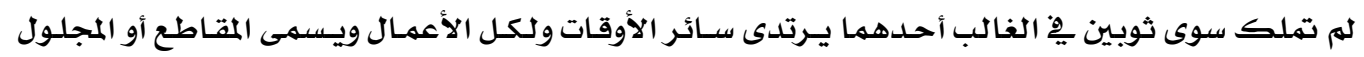

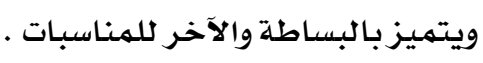

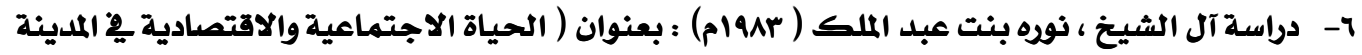

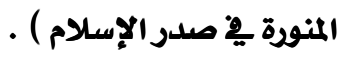

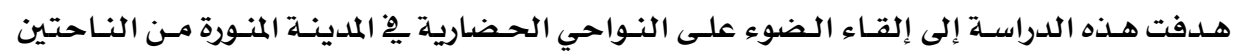

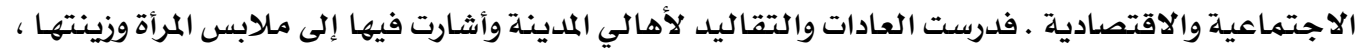

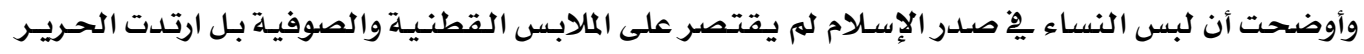

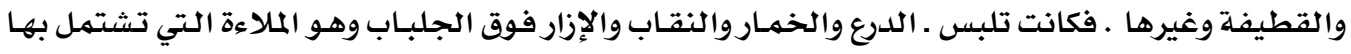
المرأة فوق الدرع 


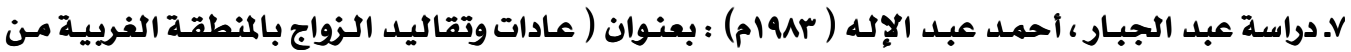

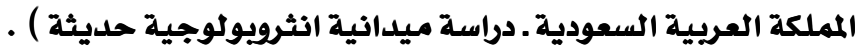

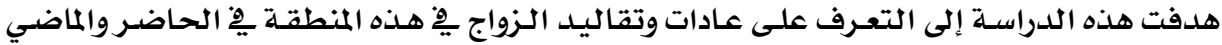

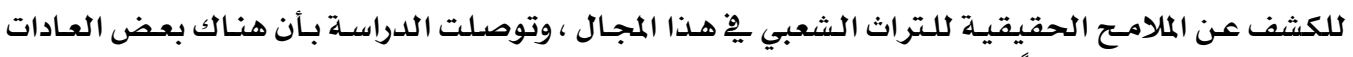

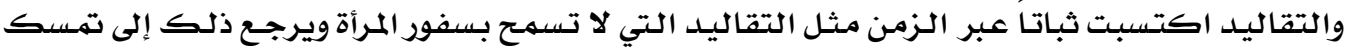

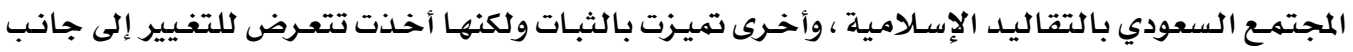

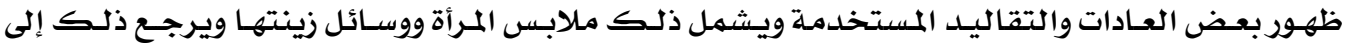

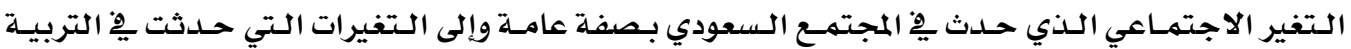
والتعليم والتنشئية الاجتماعية للأسرة. التعليق على الدراسات السابقة :

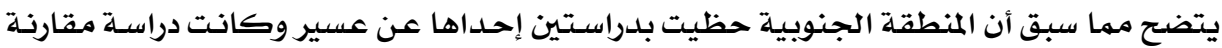

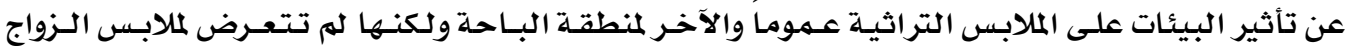

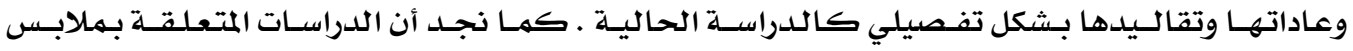

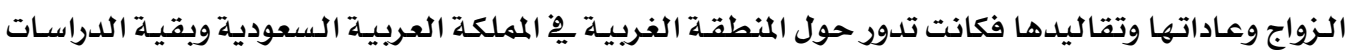
كانت عن الملابس التقليدية بصفة عامة هِّ مكة المكرمة ونجد .

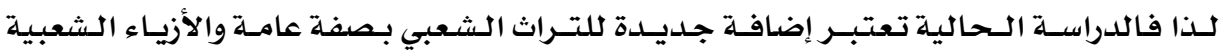
بصفة خاصة بالتوثيق والتحليل العلمي . عادات وتقاليد الزواج هِّ بلاد بنى شثر بـر

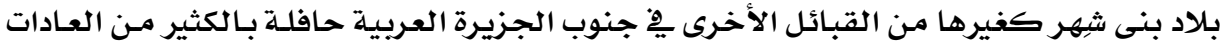

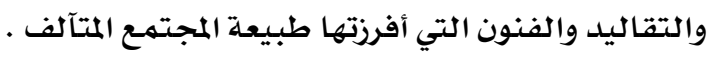

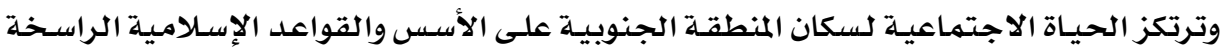

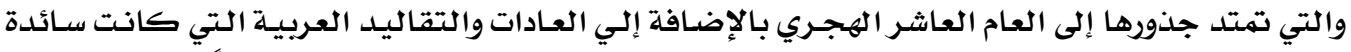

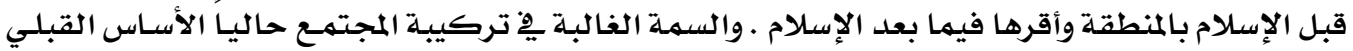

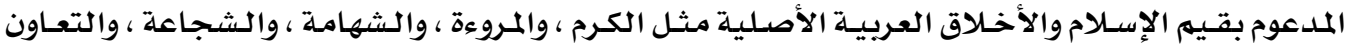

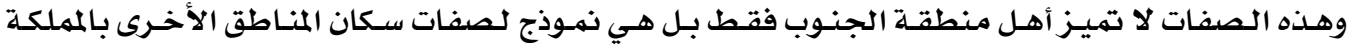

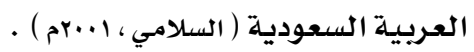

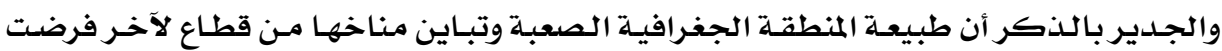

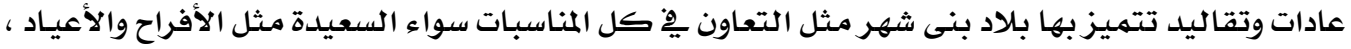

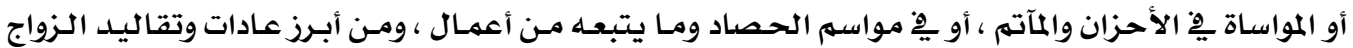

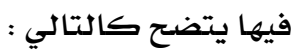

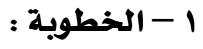

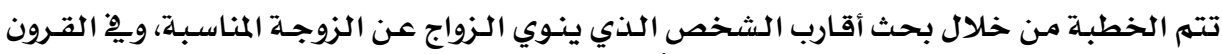

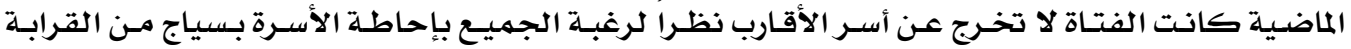




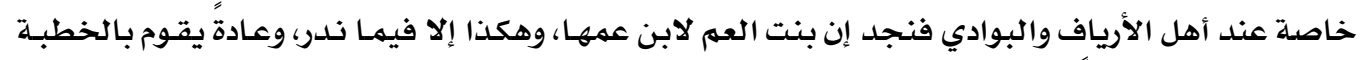

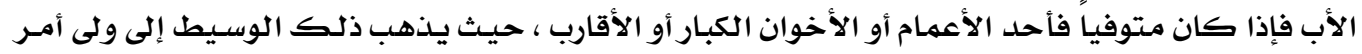

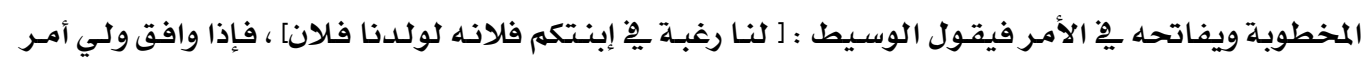

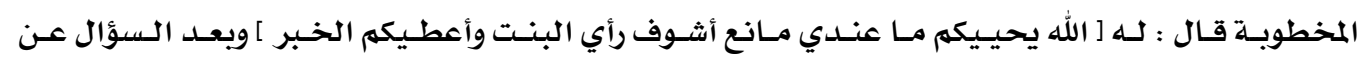

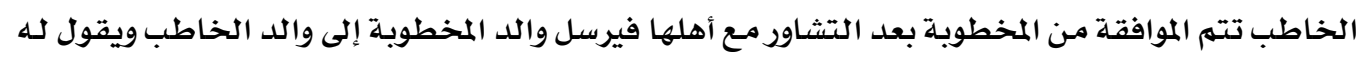

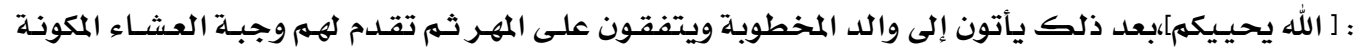

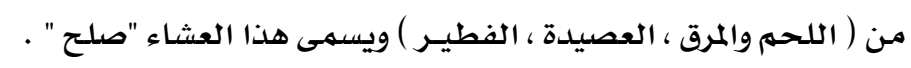

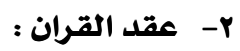

بعد اختيار الزوجلة المناسبـة ورضـا كل من الطرفين واقتناع كل منهما بالآخر يتهم عقد القـران .

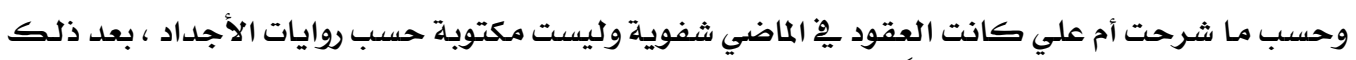

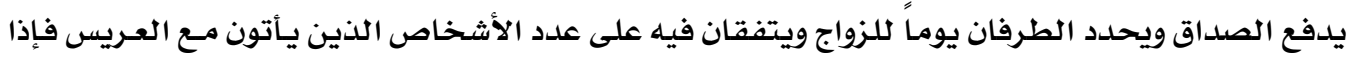

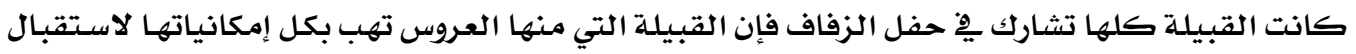
العريس وقبيلته . : r

كانت المهور ِِّ الماضي قليلة لضيق اليد حتى أنه يقال أن المهر لهم يزيد عن العشرة ريالات للبكر،

$$
\text { وأقل من ذلك للثيب . }
$$

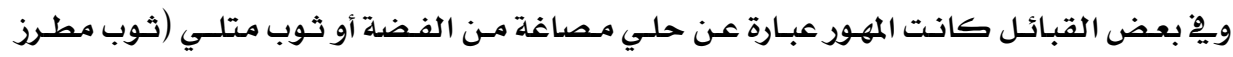

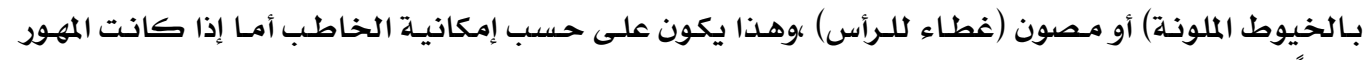

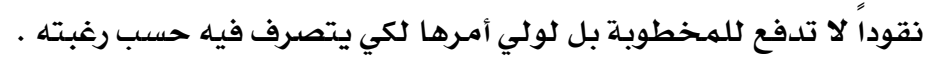

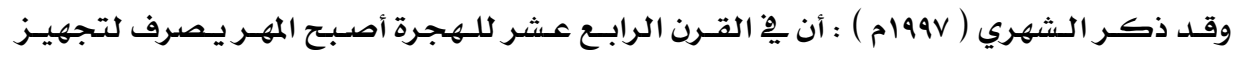

المخطوبة ، وأن بعض الآباء وأقارب المخطوبة يدفع من مالده الخاص لتجهيز العروس ومنهم قبائل بني شهر

ع ـ العلاقة بين الخطيبين :

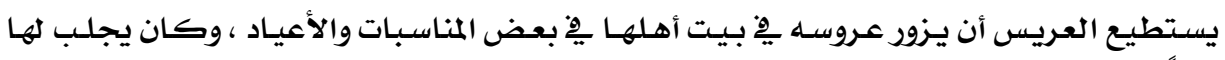

الهدايا تقديرا لعروسهـ .

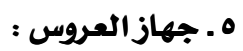

تجهزز العـروس من قبـل أهلها وذلك حسب يسرهم ويكون يْ الغالب عبارة عن :

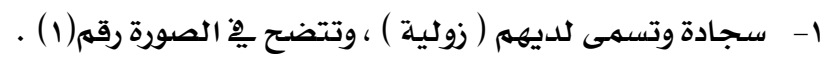

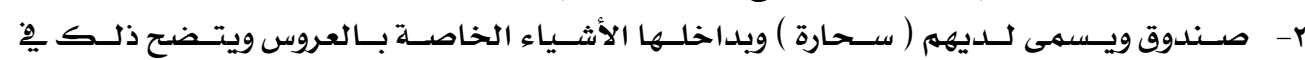

الصورة رقه (r ) )

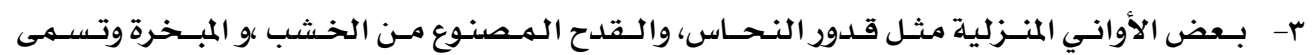

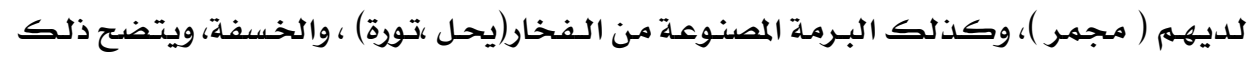

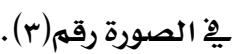

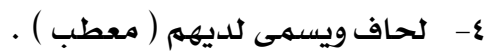




$$
\text { ه- بقرة وتسمى لديهم ( حوز) . }
$$

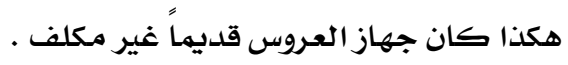

7 .

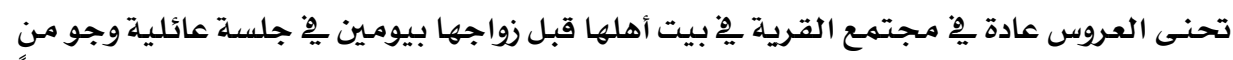

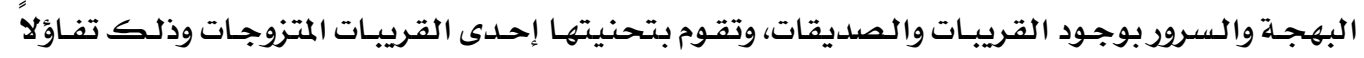

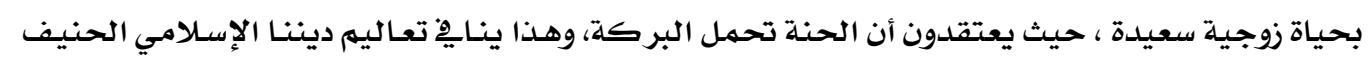

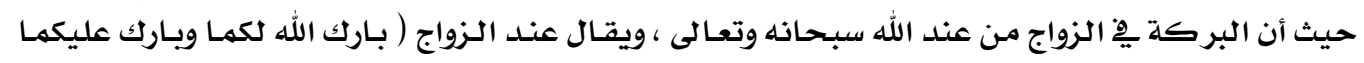

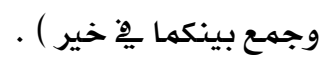

وتحنى العروس أيديها وأرجلها، وتسهى حنة اليد ( القبضدة ) ويكون لون الحنـة حمـراء أو سـوداء

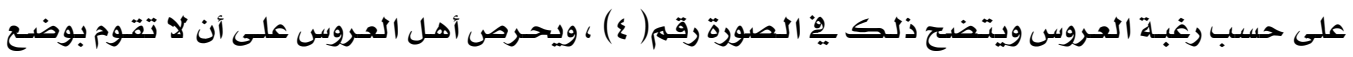

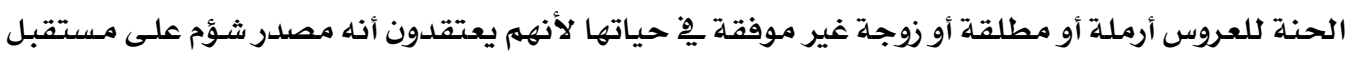

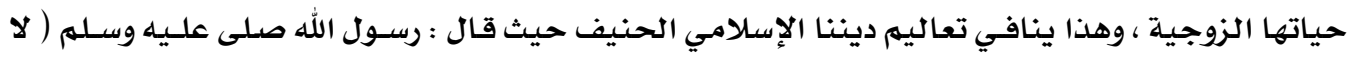

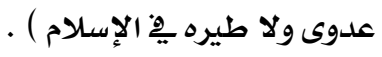

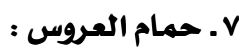

تقوم بعض قريبات العروسـة أو أخواتها بالاهتمام بالعروس وذلك بـدهن شعرها وجسمها بـبعض

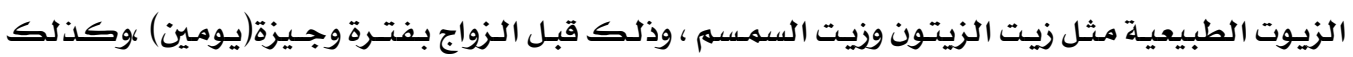

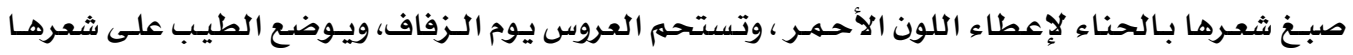

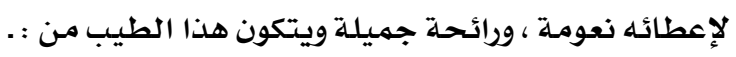

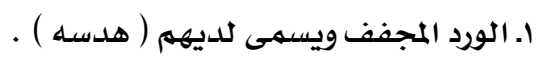

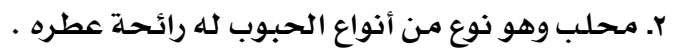

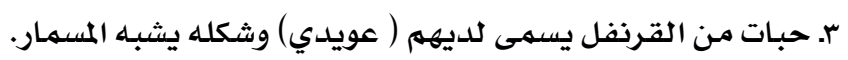

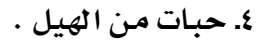

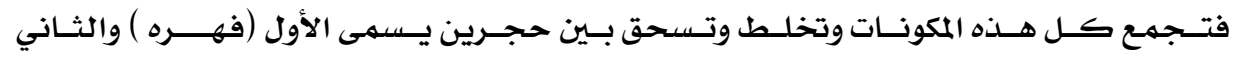

(مسحقة) وهي القاعدة، ثم يوضـع الطيب المسحوق على شعر العروس،ويتضح ذلك يخ الصورة رقمى (ه ).

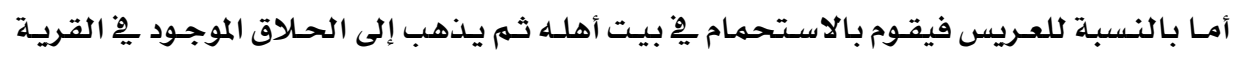

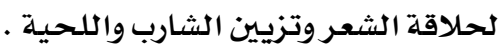

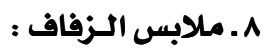

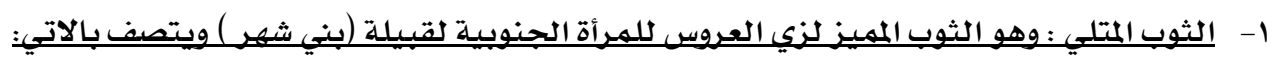
الشكل العــام للثـوب : عبـارة عن ثوب طويـل بطـول المرأة ويتسـع تـدريجيا مـن الأعلى إلى أسفل

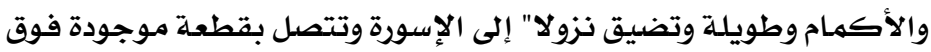

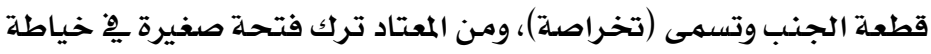

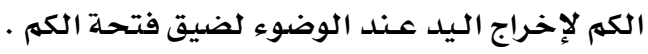


حـــــردة الرقبـــــة:عبارة عن حردة دائريـة صغيرة وبها فتحـة طولية مـن الأمـاموقد تكون الحـردة مريعة متسعة قليلا وذلك لتسهيل مرور الرأس.

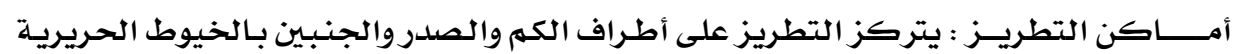
الملونة والقصب.

الغــــرز المســـتخدمة: غرزة السلسلة.

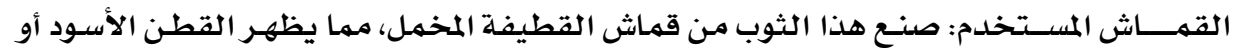

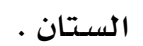

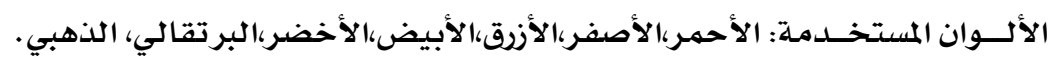

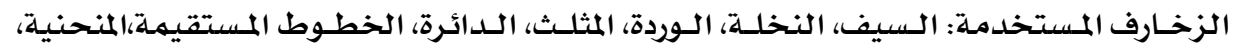

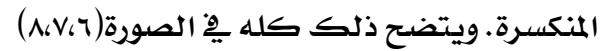

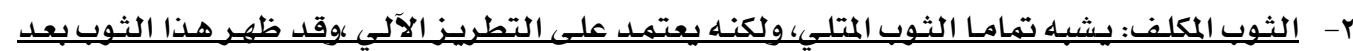
ظعهور الآلة.

كما ارتدت الفتيات والشابات الملابس المصبوغة بالأخضر والأحمر . r-

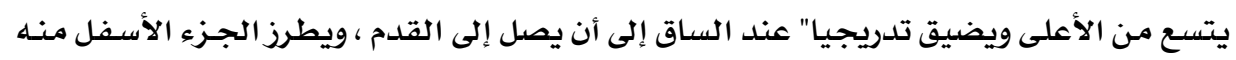

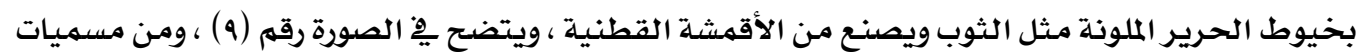

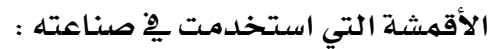

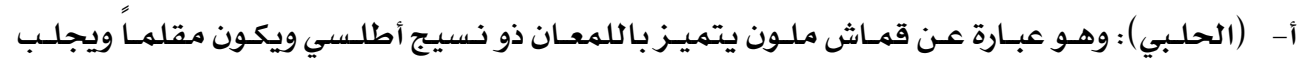
من حلب .

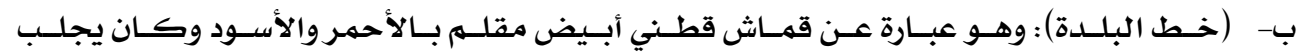
من مصر - من ع- المنديل : وهو عبارة عن قماث قطني خفيف ملون باللون البرتقالـي أو الأحمر أو مزخرف بالورود المطبوعة

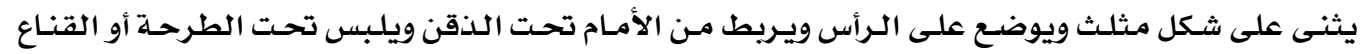

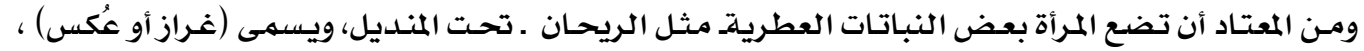

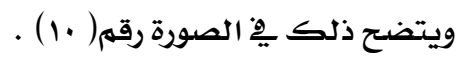
-

ويسهى شـيلـة أو مسفع : وهـو عبـارة عـن غطلـاء للـرأس مستطيل مـن القطن الأسـود الخفيف لـهـ

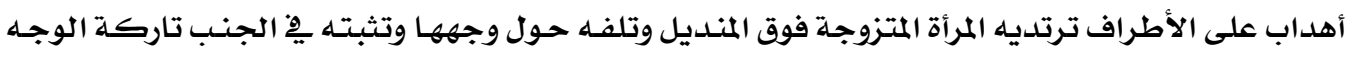

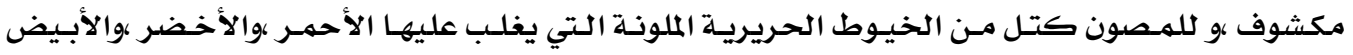

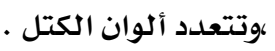

وترتـدي المرأة المصون، بحيـث تضع طرفها على منتصف الـرأس بشكل عرضـي ويتـدلى الطـرف الثاني ، ويتضح ذلك يِ الصورة رقم( 11 ) . 
تلسبس العـروس مـا أمكنهـا مسن الحلـي المـصاغة مـن الفـضة لاسـتكمال مظهرهـا وزينتهـا ، وهـي كما يلي :

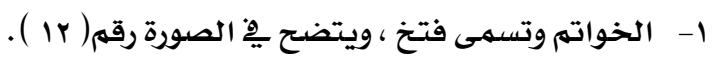

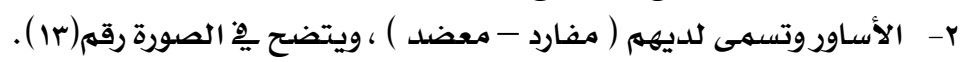

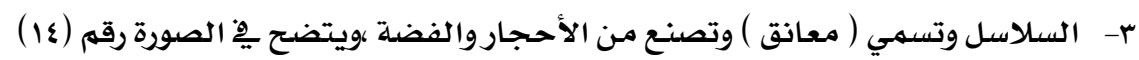

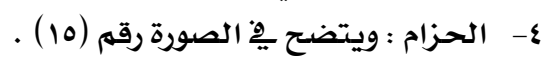

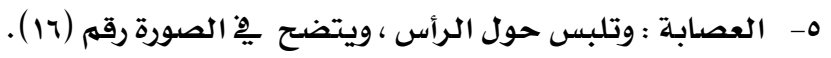
. - إينة عين العروس :

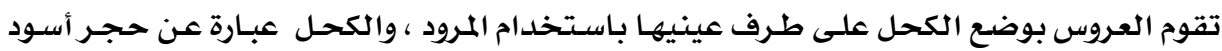

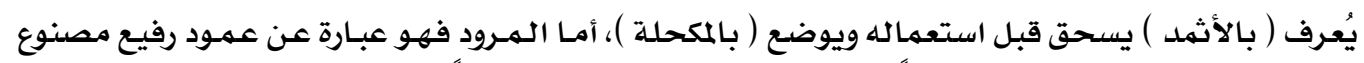

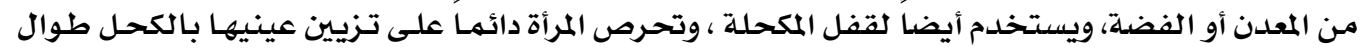

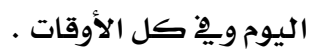

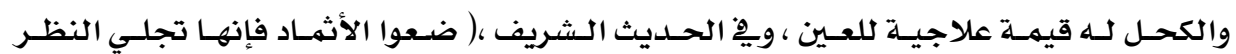

$$
\text { وتطيل الأهداب (واجل ) }
$$

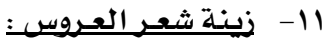

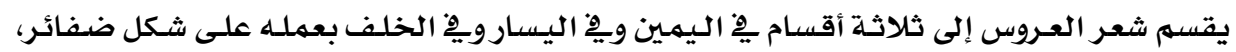

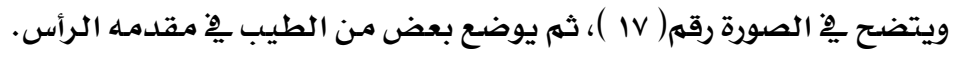

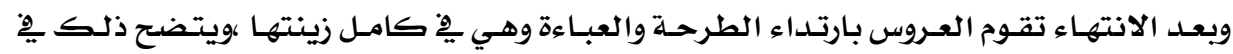

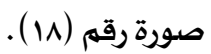
:

يِّ صباح اليوم المتفق عليه للزفاف يذهب العريس ومعحه عدد من رجال قبيلته وعند الاقتراب مـن

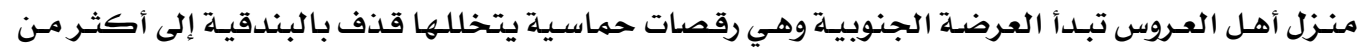

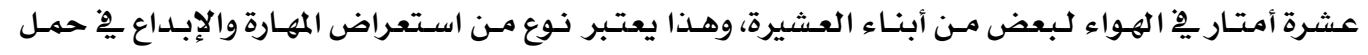

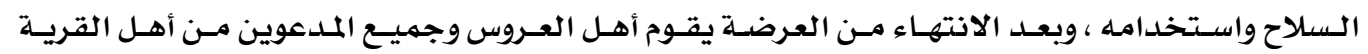
بالترحيب بهم ثم يقدمون لهم القهوة ،والرطب ، وبعدها يتناولون بعض المأكولات الشعبية مثل :

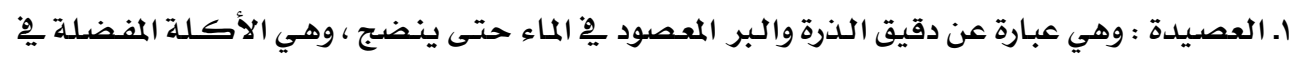

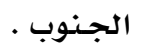

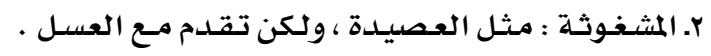

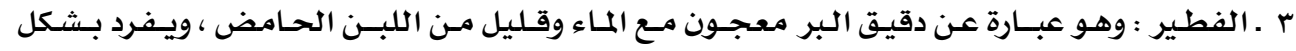

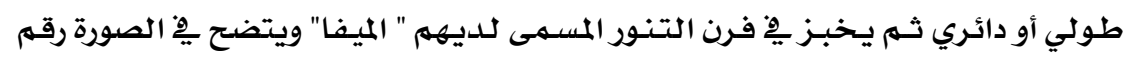

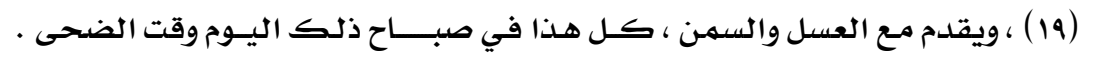




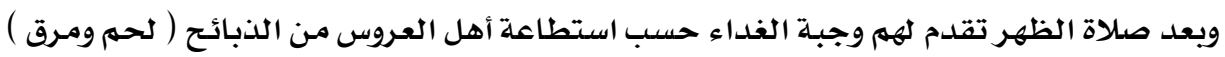

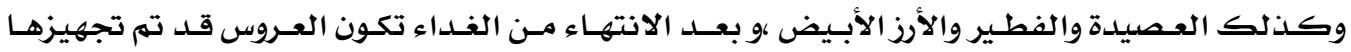

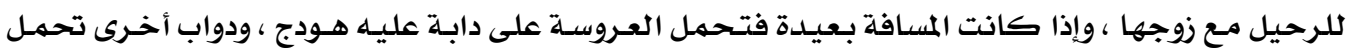

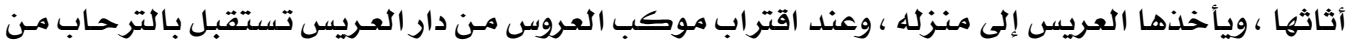

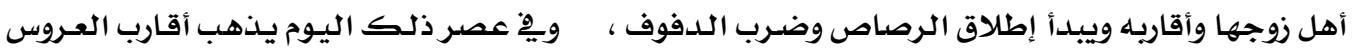

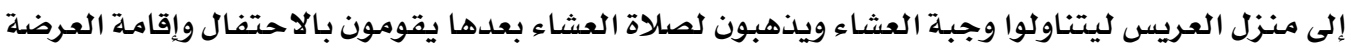

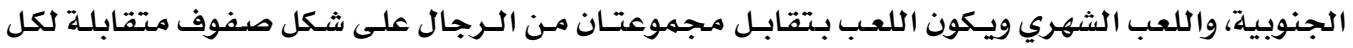

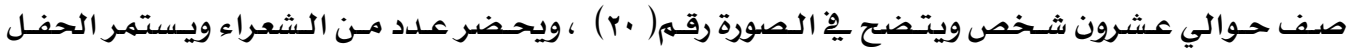

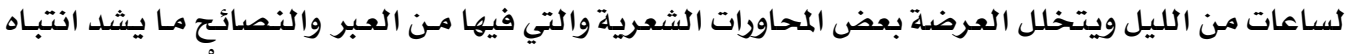

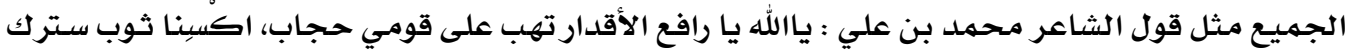

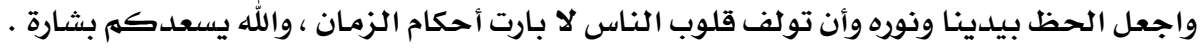

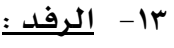

من العادات البارزة والمرتبطة بمناسبة الزواج وهو أن يقدم الأقارب والأصدقاء كلا" حسب قدرته ،

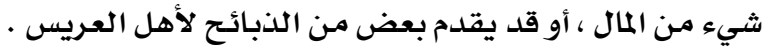

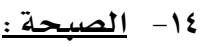

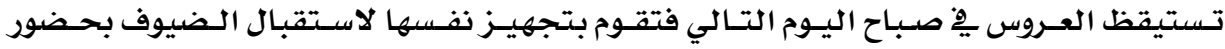
والدتها التي تجلب معها الفطور المكون من الآتي :

ا- العريكة : عبارة عن دقيق بر معجون بالماء .

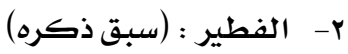

r- الأقراص: ت تكون من دقيق البر معجون بالماء وخميرة، وتكون الأقراص خفيفة .

أما العروس فتجهز بعض المشروبات مثل :

1- قهوة الهيل : وهي عبارة عن البن بإضافة قرنفل وقرفة وزنجبيل وهيل وتقدم ميح التمر .

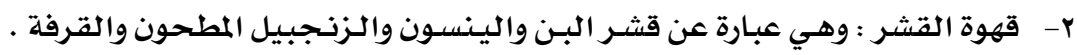

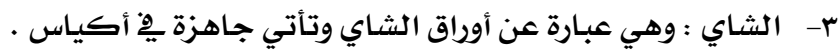

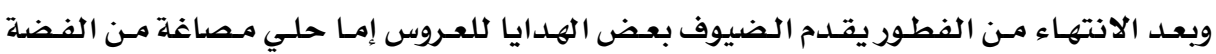

10

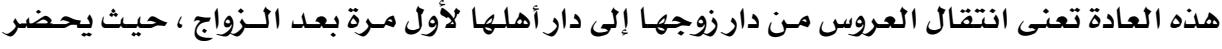

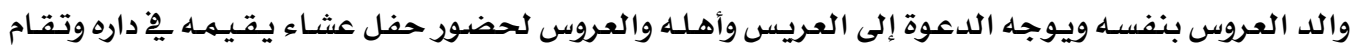

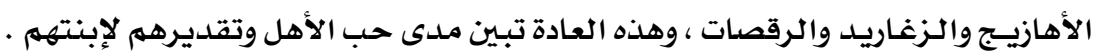




\section{إنيت النزوحيـة}

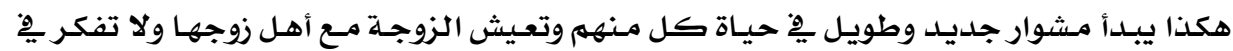

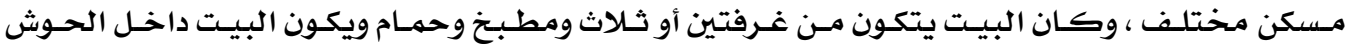
(حديقة البيت) (حسن محند).

والبيـوت كانت عبـارة عن أحجـار مبنيـة فوق بعضها لا تزيـد عن ثلاثة أدوار ، والنوافذ والأبـواب

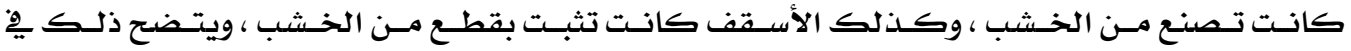

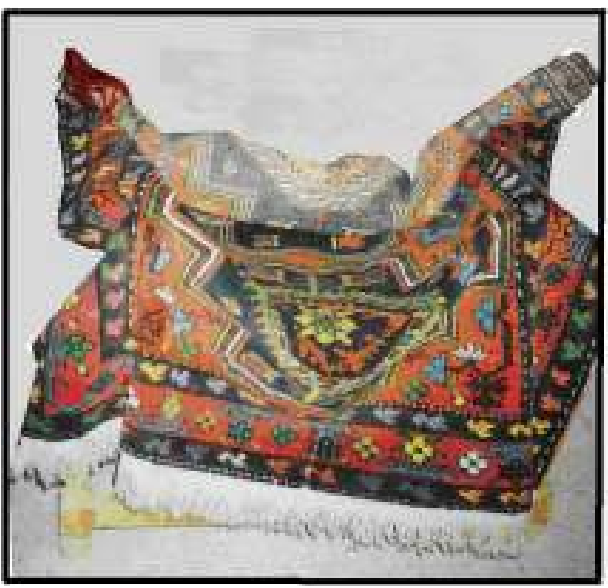

الصورة رقم (r) (r) (ب)

صورة رقم ( 1 ) سجادة صغيرة ( زولية )

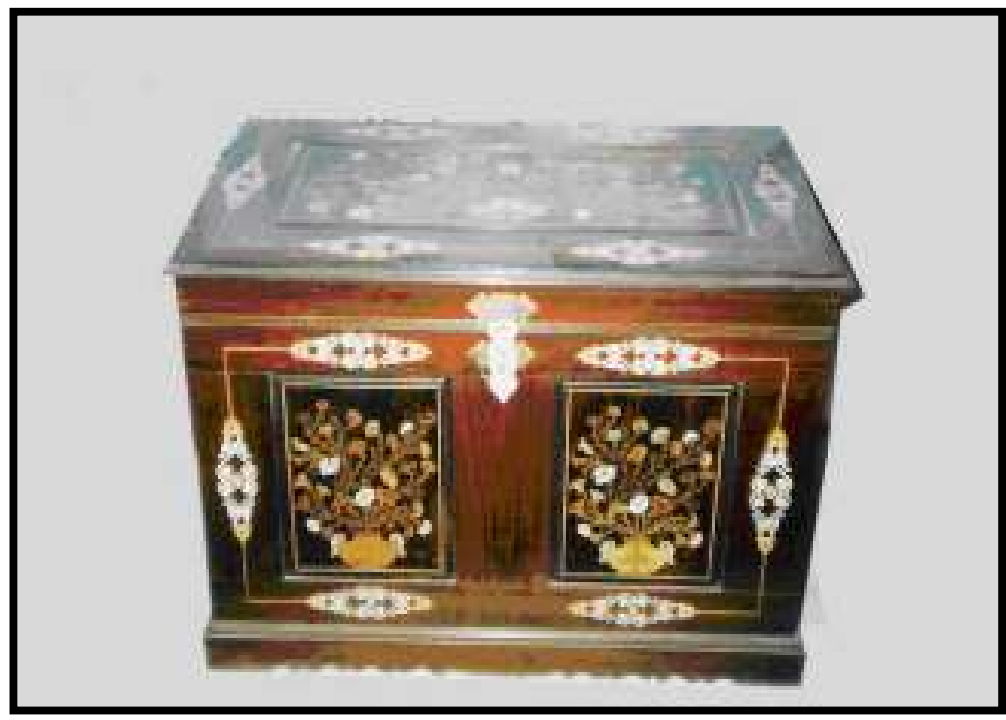

صورة رقم ( r ) صندوق خشب ( سحارة ) 
التراث والأزياء بِ عاداتو تقاليد الزواج بِّ بلاد بنى شيهر
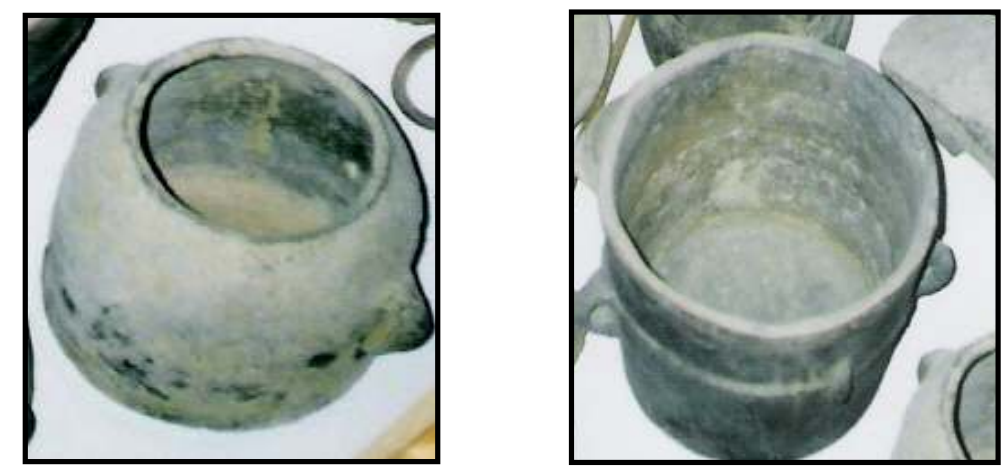

أنواع مـن البرمة (يحل ، تورة)

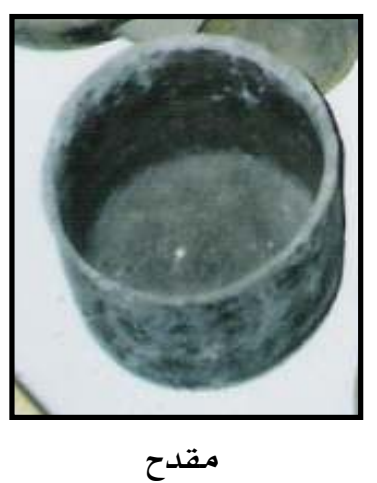

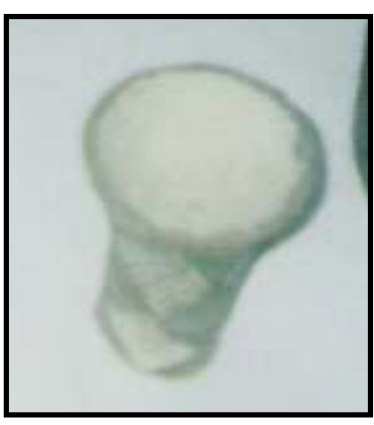

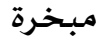

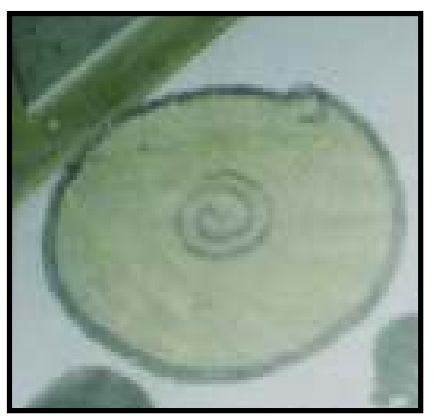

خسفة

صورة رقم (r) أنواع من الأواني المنزلية

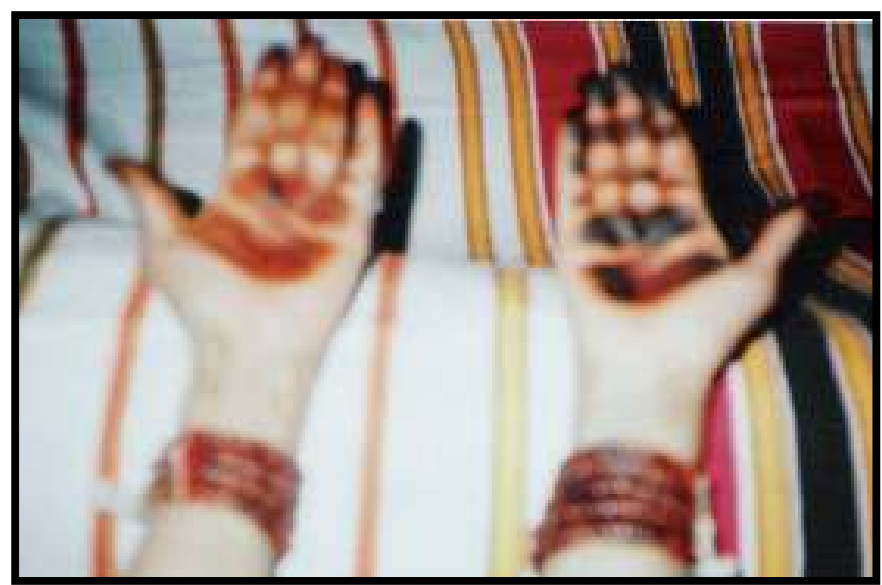

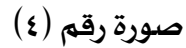

تبين حنة اليد (القبضة) اليد اليمنى حنة سوداء ،واليد اليسرى حنة حمراء 


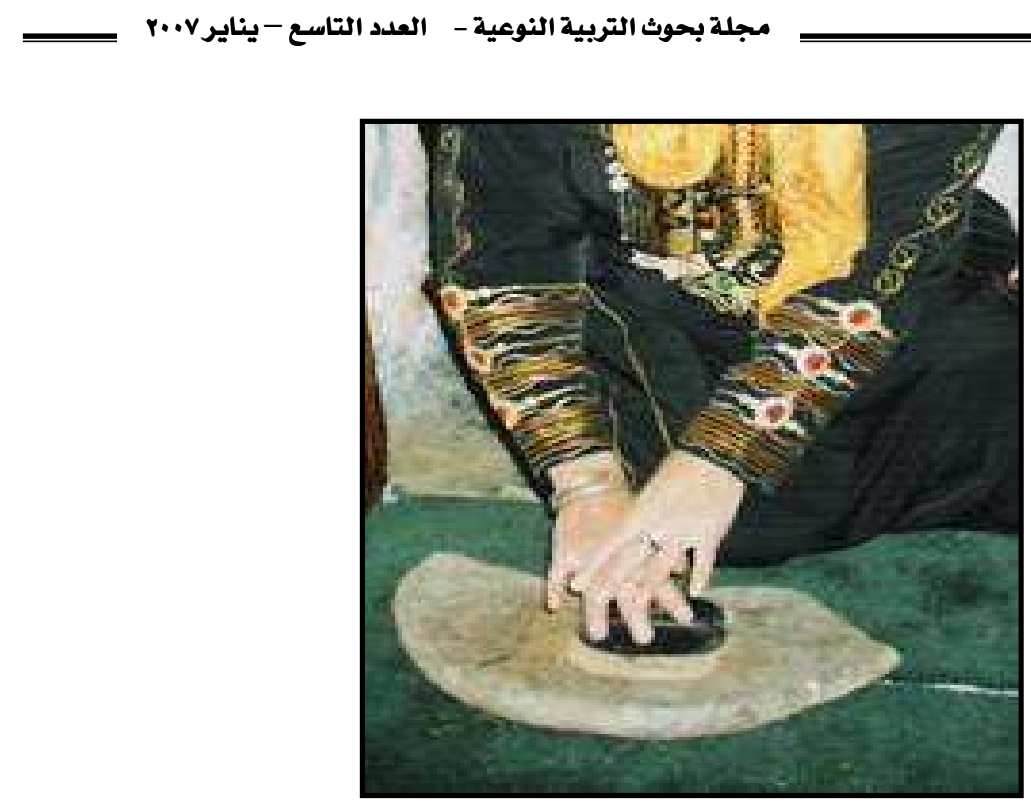

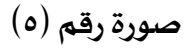

تبين الحجرين الذي يتم به سحق مكونات الطيب ( هدسة ،محلب ،عويدي وريحان )
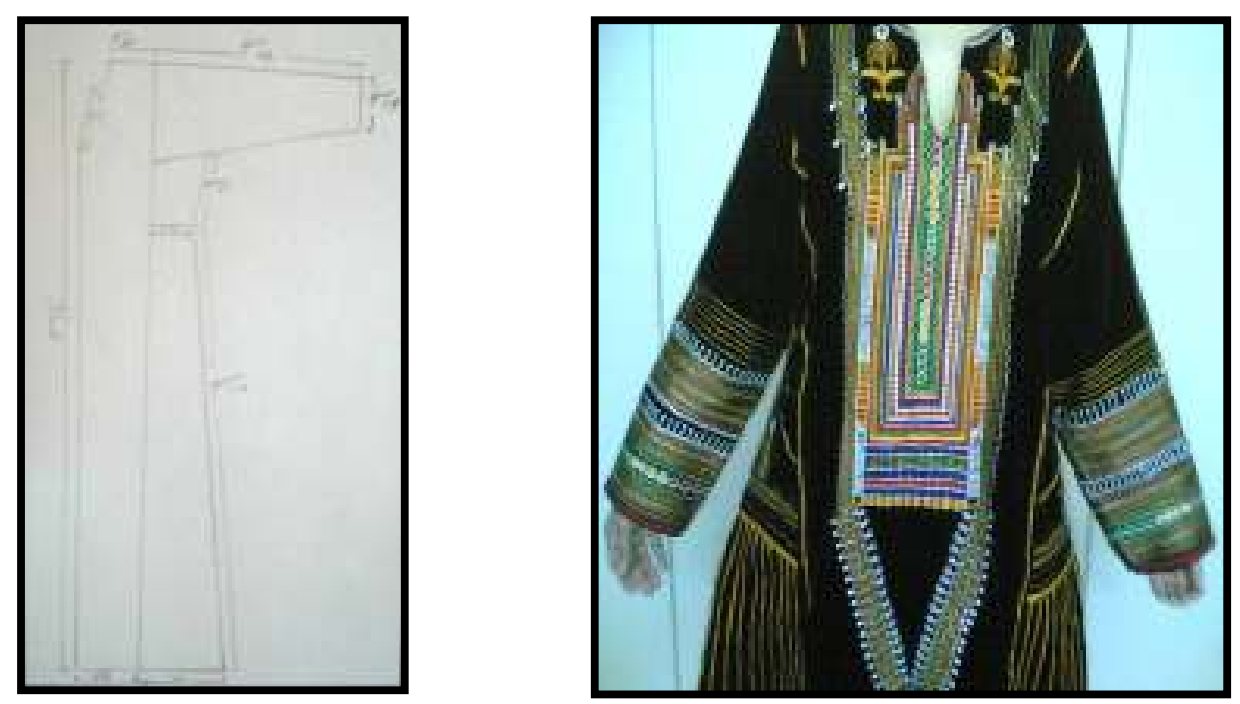

صورة رقم (7) الثوب المتلـي من الأمام ومقاساته 


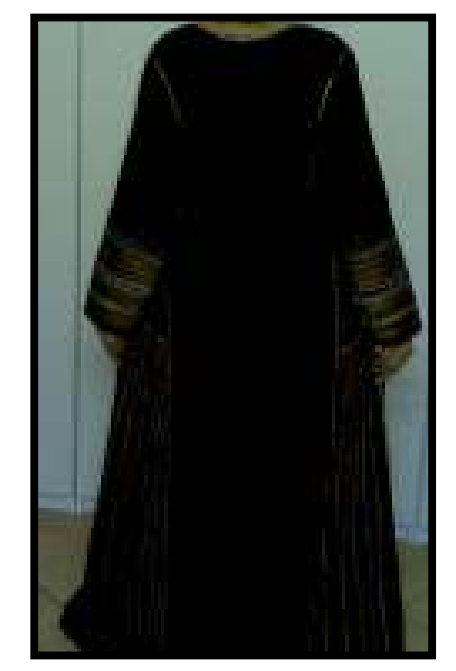

صورة رقم (v) الثوب المتلسي من الخلف

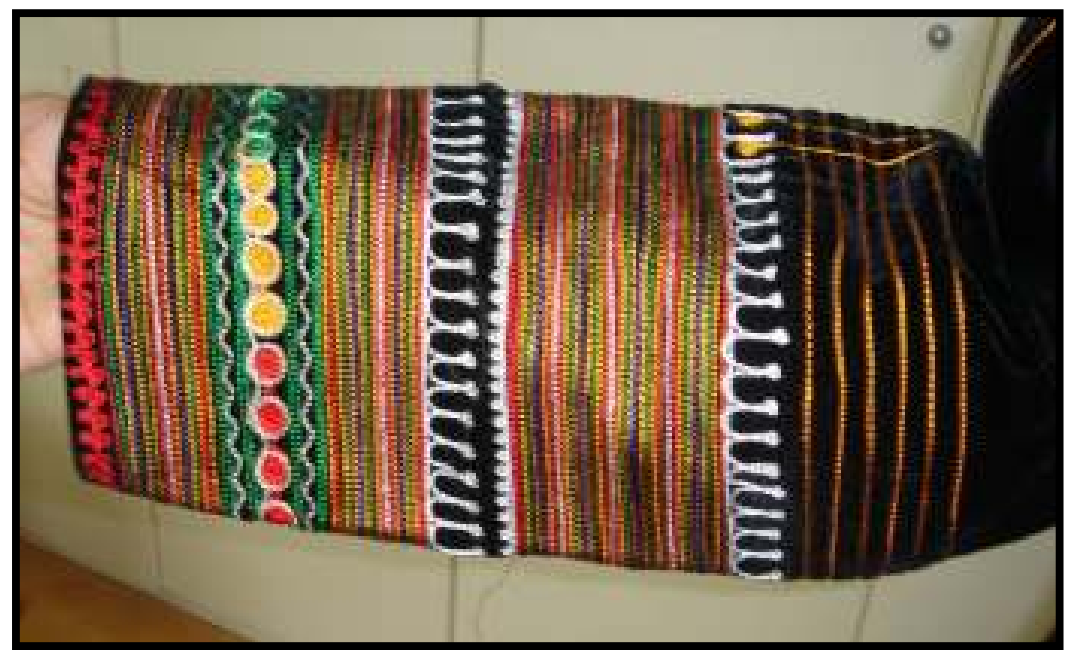

صورة رقم (^) إسورة الكم للثوب المتلي 


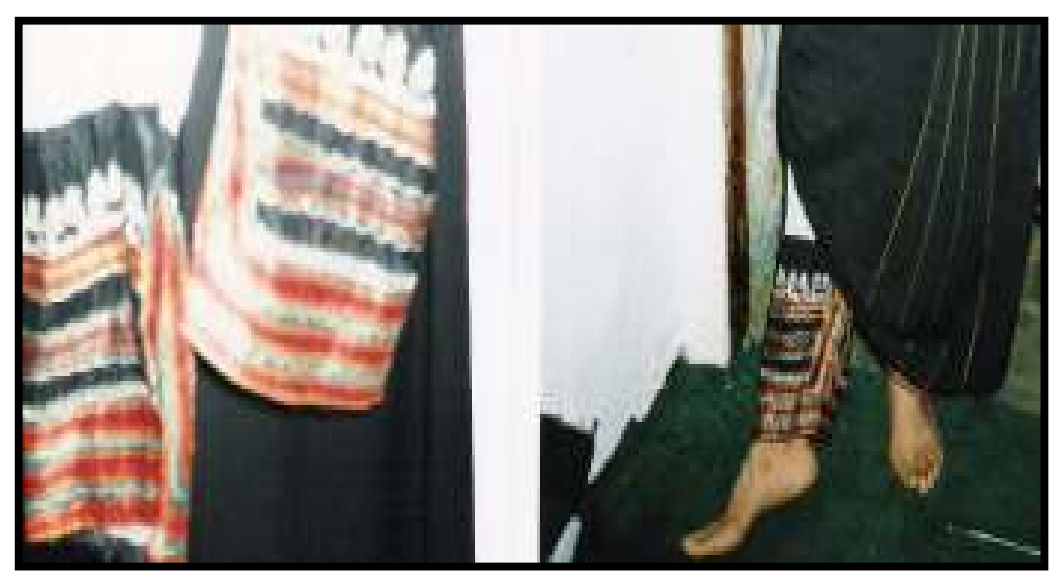

$$
\text { صورة رقم ( } 9 \text { ) تبين تطريز السروال }
$$

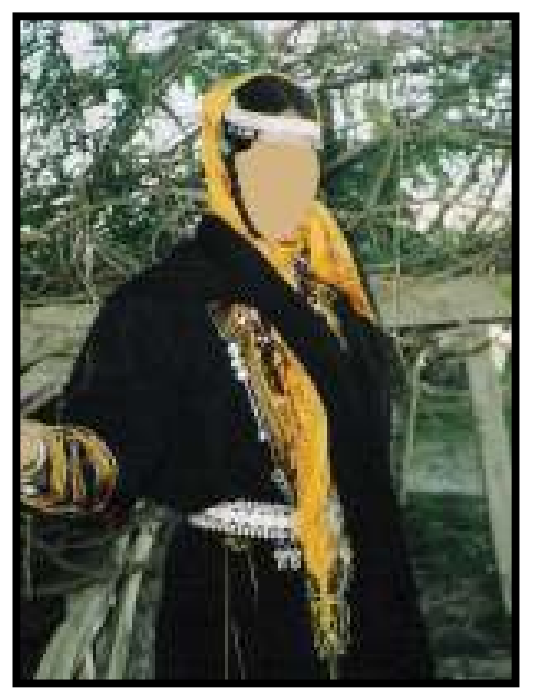

صورة رقم ( . 1 ) فتاة ترتدي المنديل بعد أن وضعت الريحان 

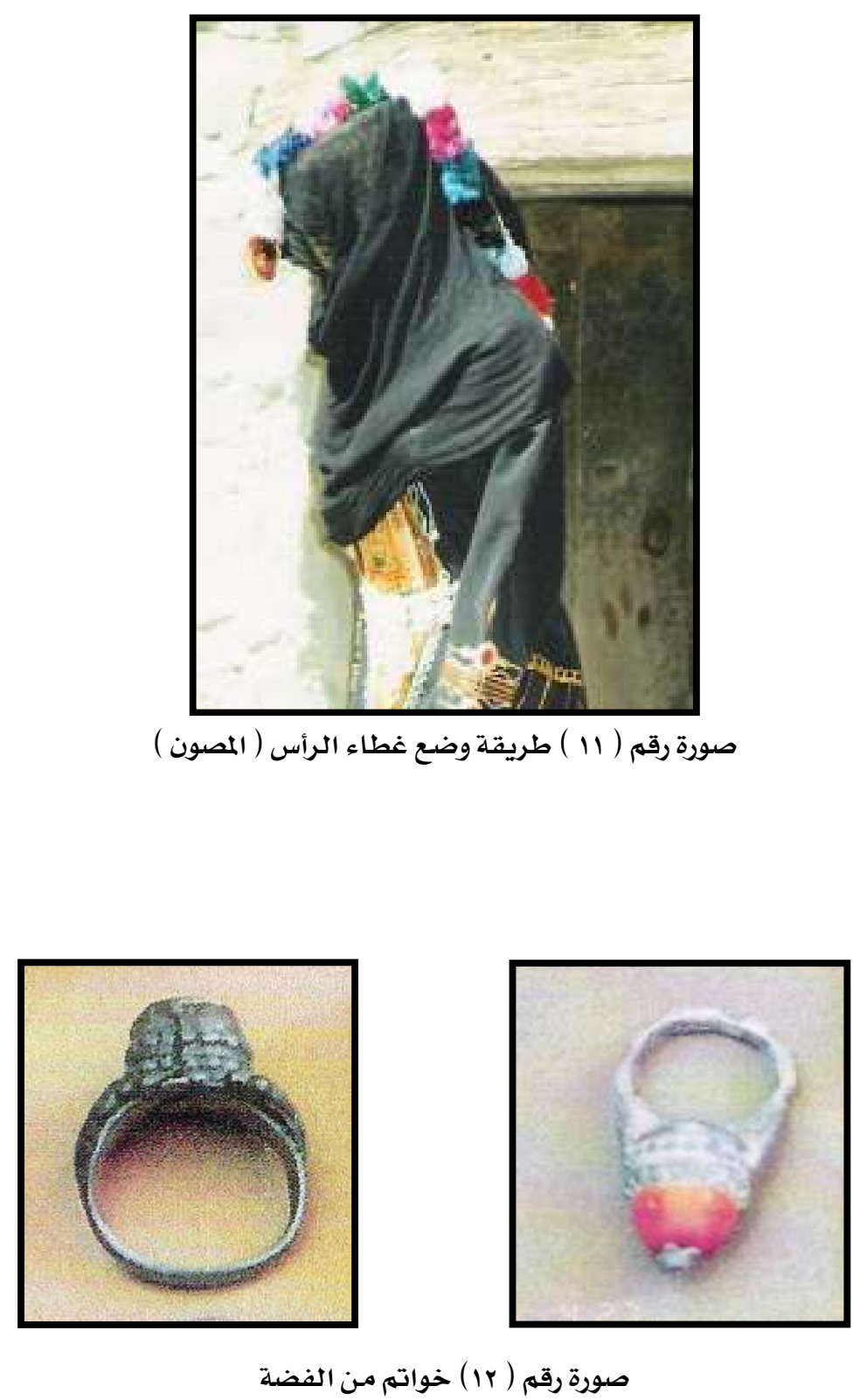

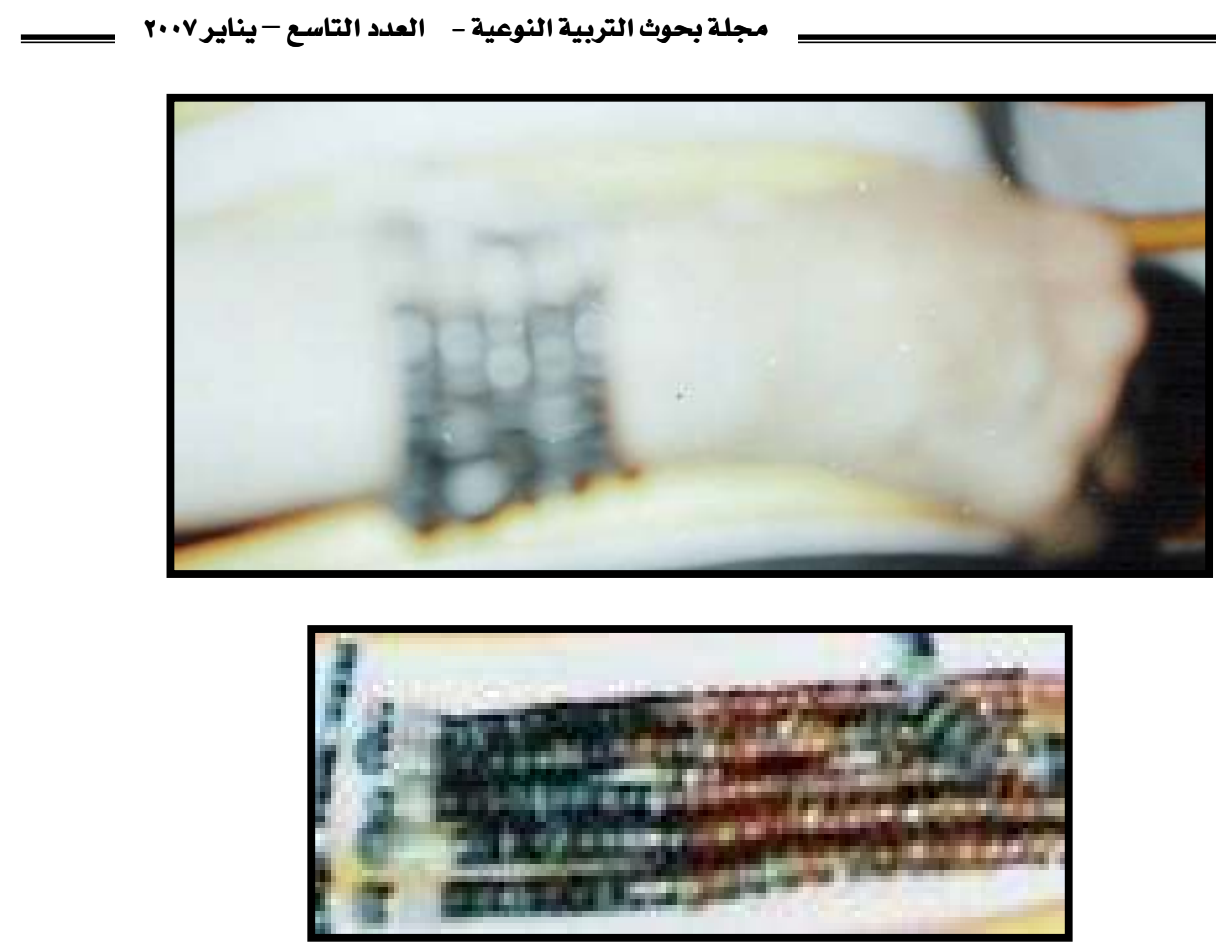

صورة رقم ( سا ) الأساور ( المفارد ـ المعضد )
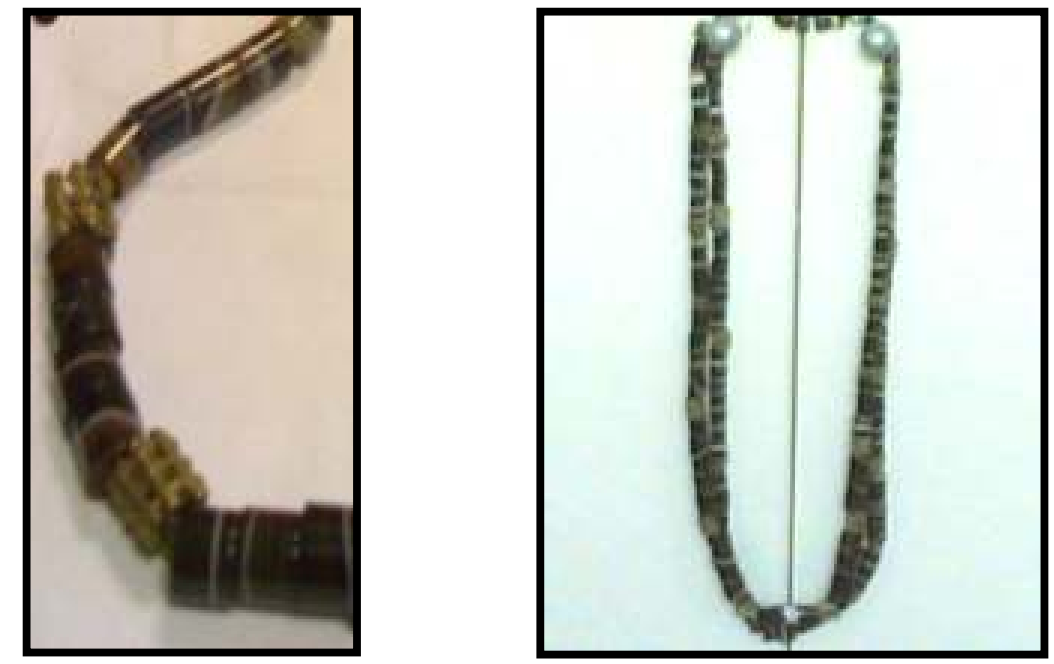

صورة رقم ( ع ) السلاسل ( معانق ) 


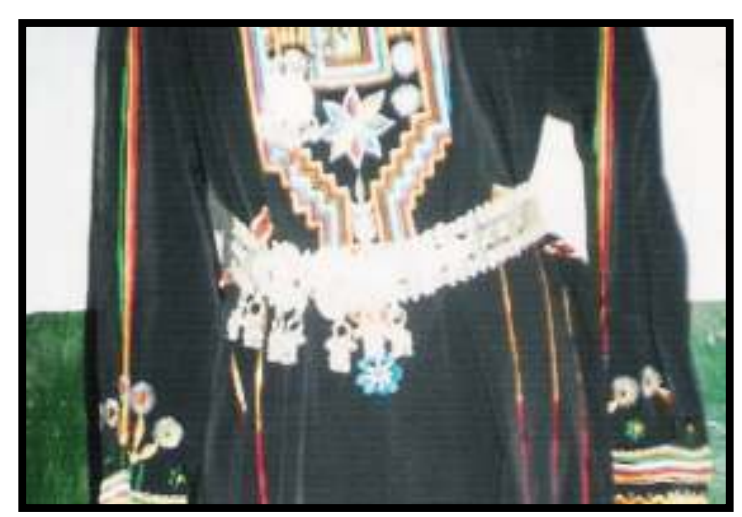

صورة رقم ( 10 ) الحزام الفضي
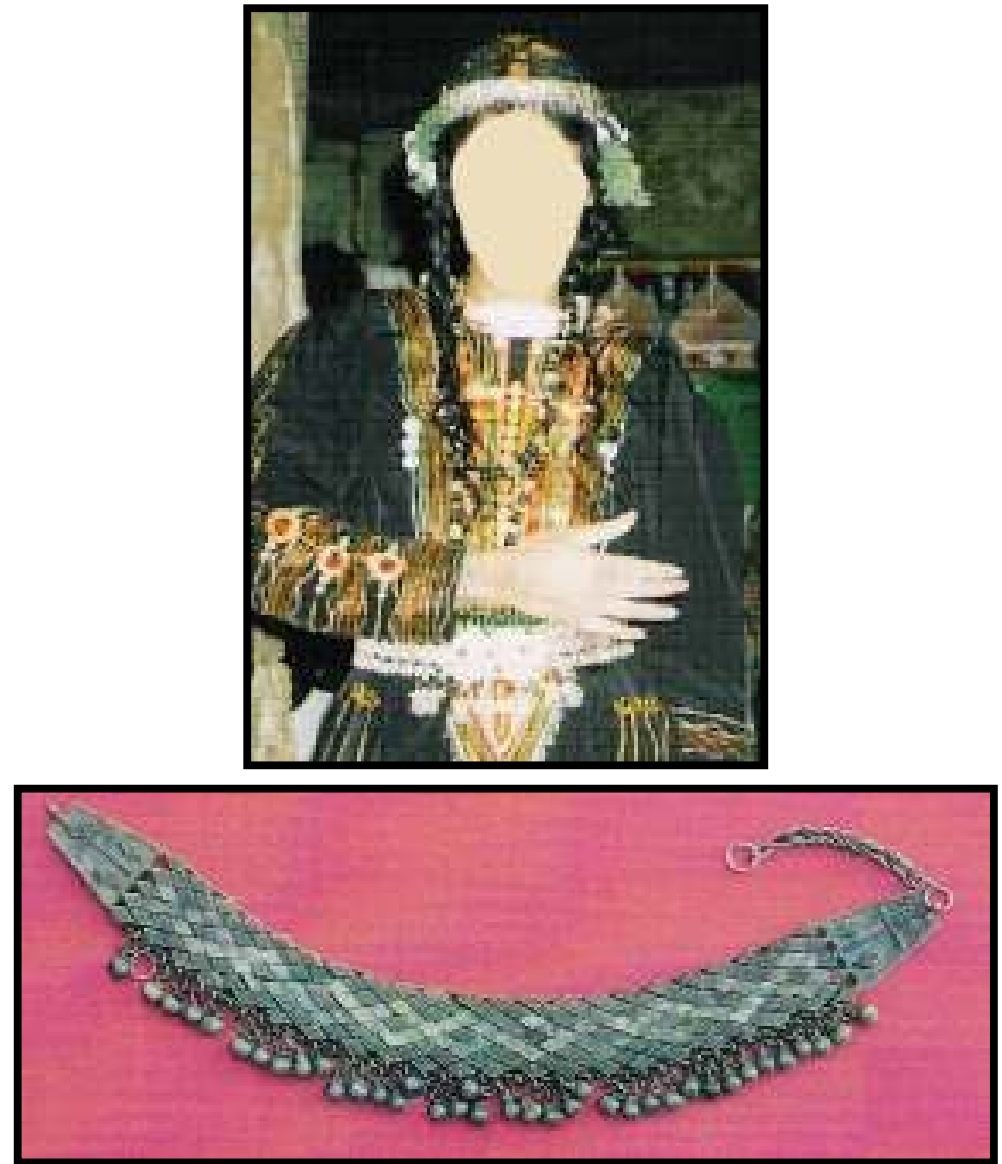

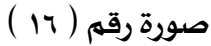

العصابة الفضيـة التي توضـع على الرأس وترتديها المرأة مـع ثوب مكلف (تطريز بالماكينـة ) 


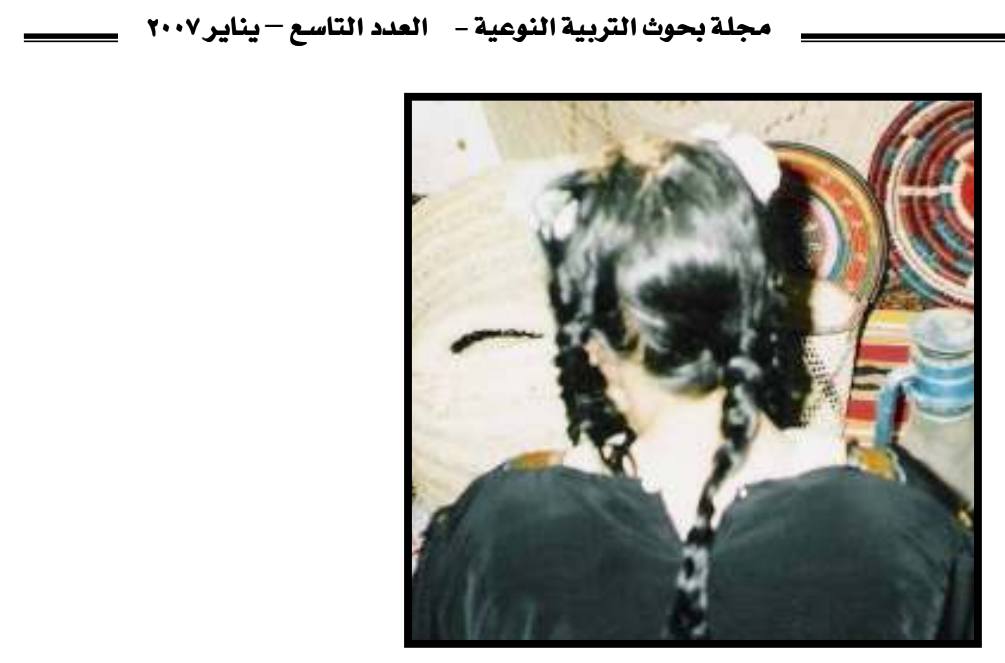

صورة رقم ( VV ) توضح كيفية تقسيم الشعر وعمله على شكل ضفائر

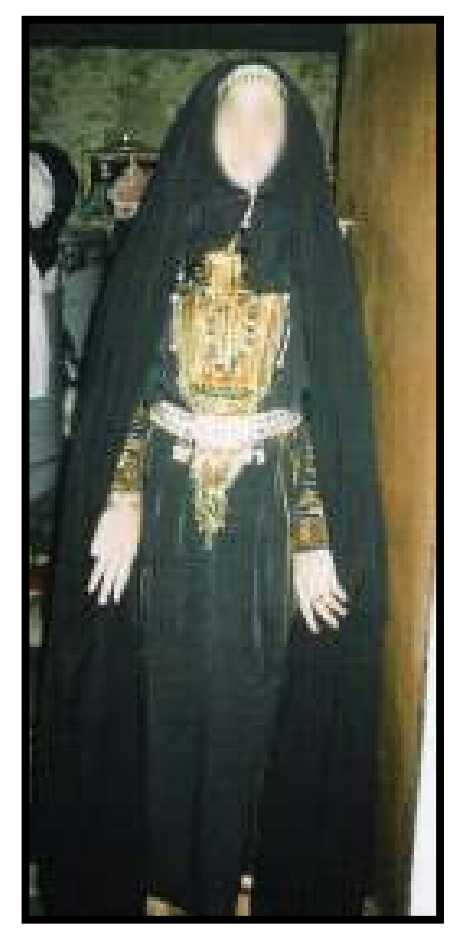

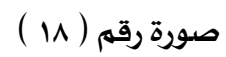

توضح العروس وهي ترتدي الثوب المكلف ِِّْ كامل زينتها بعدما ارتدت العباءة والطرحة ( القناع ) 


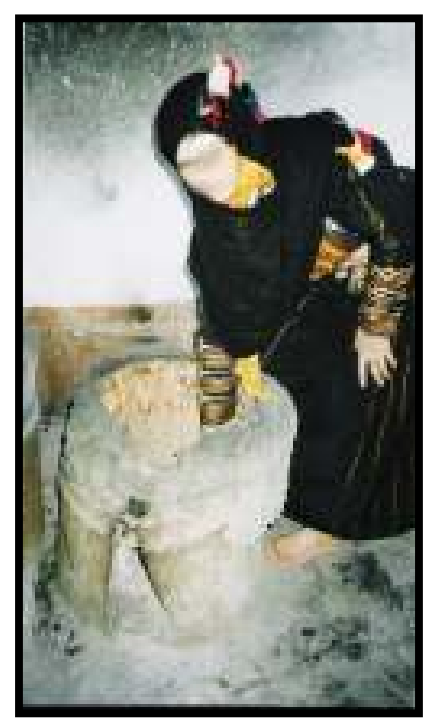

صورة رقم ( 19 ) التنور ( الميفا )
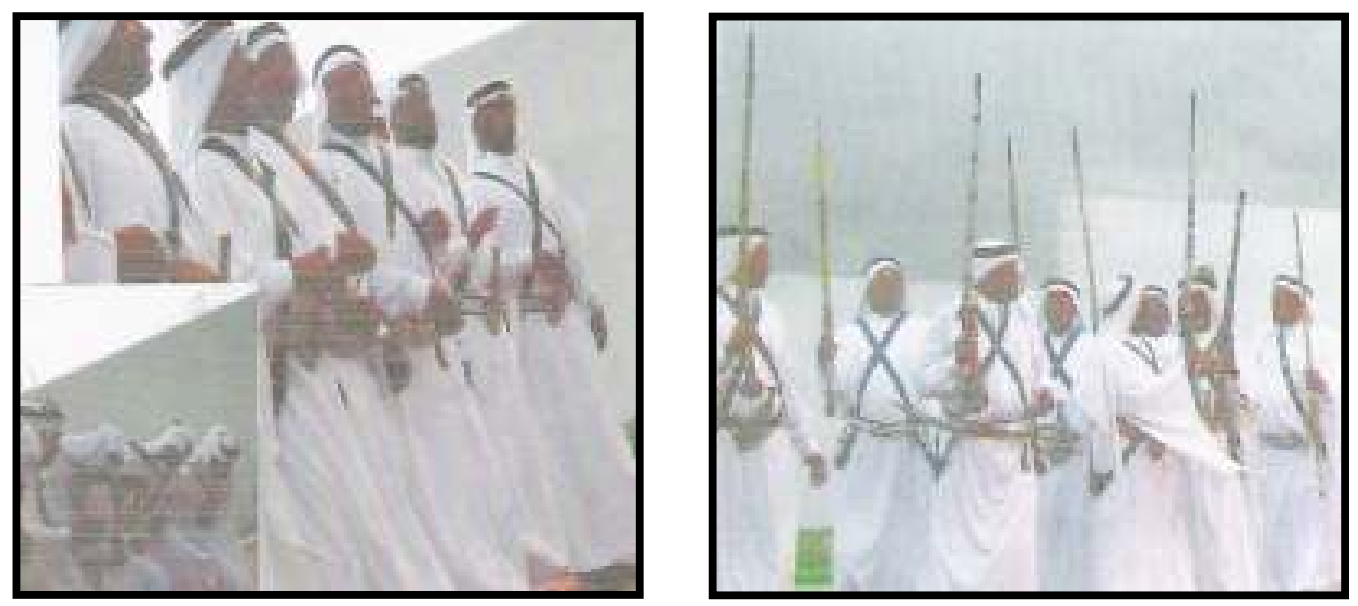

صورة رقم ( • ) توضح اللعب الشهري والعرضـة الجنوبية

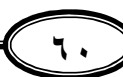



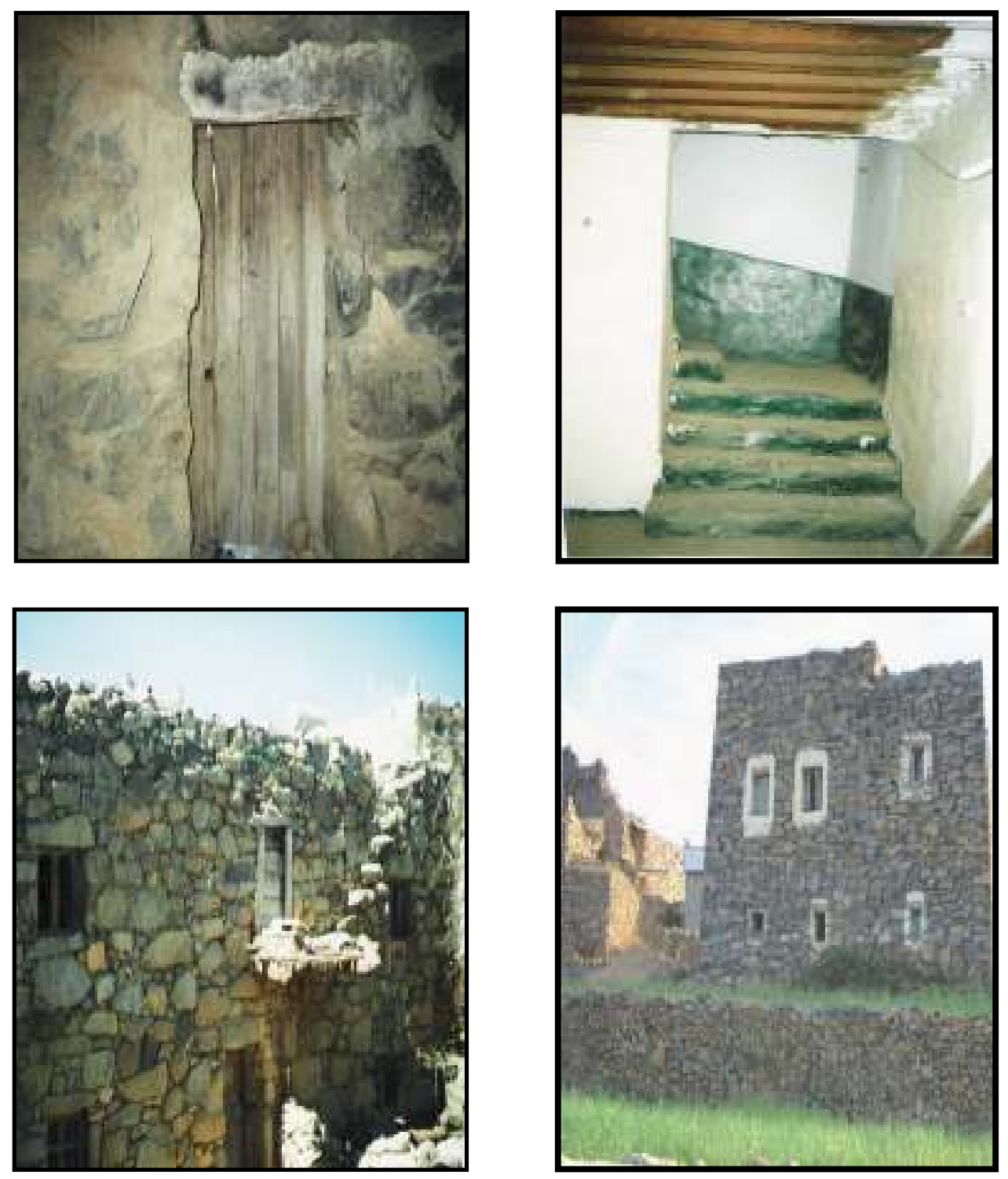

صورة رقم (Yr) تبين شكل البيوت من الداخل والخارج 
تحليل النتائج وتفسيرها

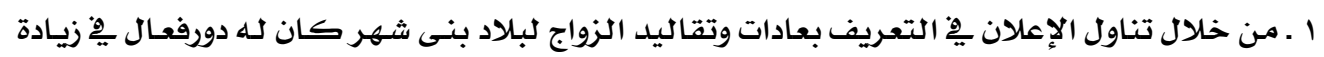

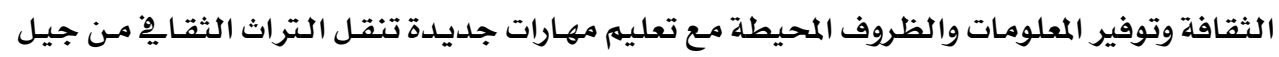
إلى جيل وتساعد على تنشئسة الجيل الجديد وافيل .

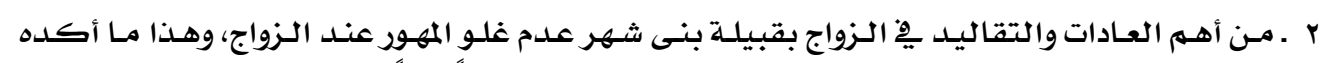

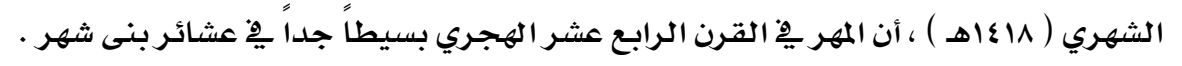

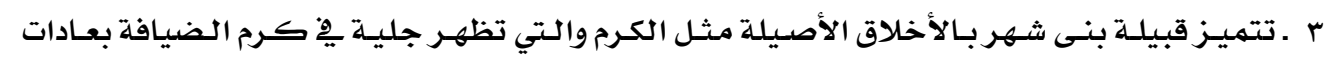

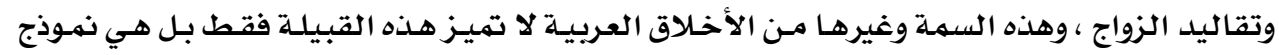

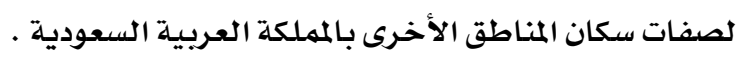

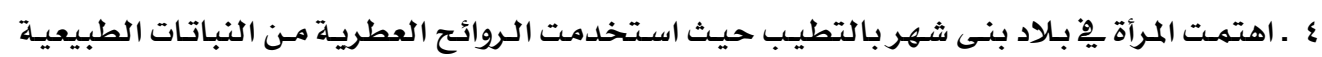

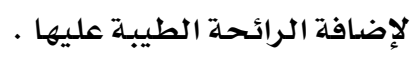

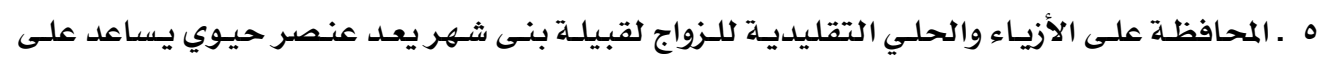

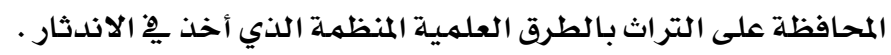

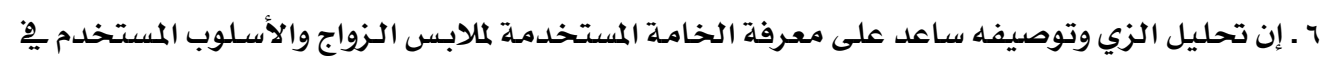

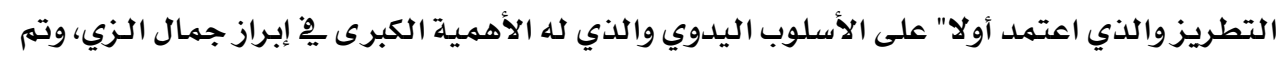

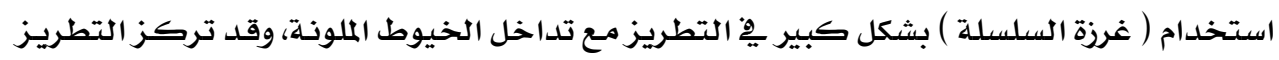

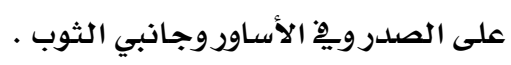

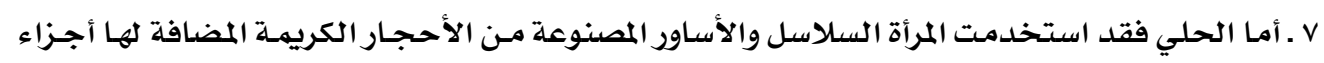

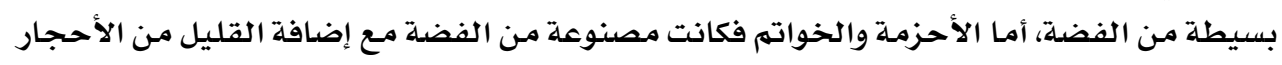

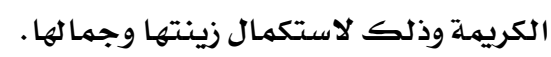

التوصيات

ا ـ دعوة الجامعات والكليات إلى التضامن والتعاون لإنشاء متحف يضمى تراث المملكسة العربيـة السعودية

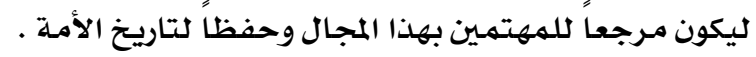

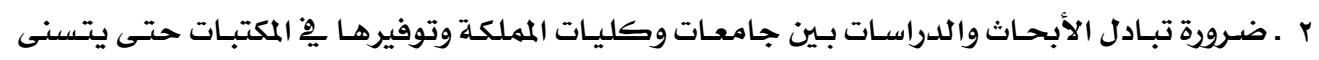

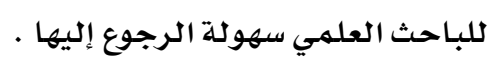

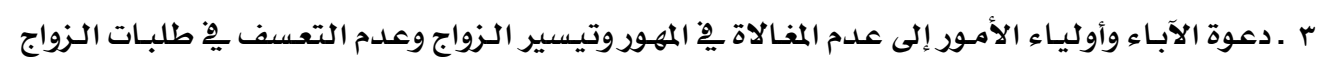

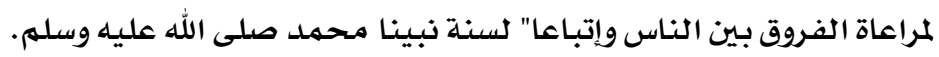

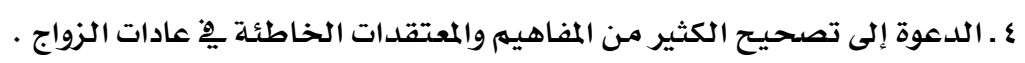

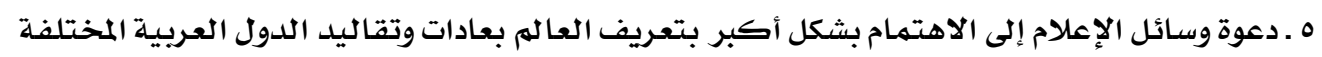
عن الزواج 
1- أبو العلا ، محمود طه ( به19 م ) : جغرافية شبه الجزيرة العربية ، طه ، مكتبة الأنجلو المصرية ، القاهرة

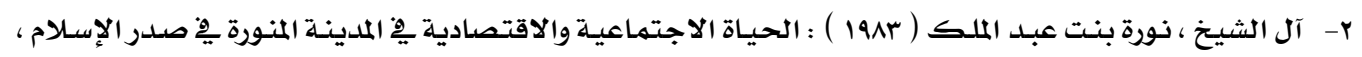
تهامـة ، جدة .

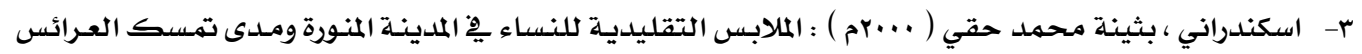

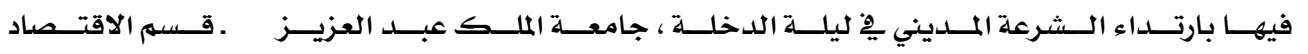
المنزلي . جدة .

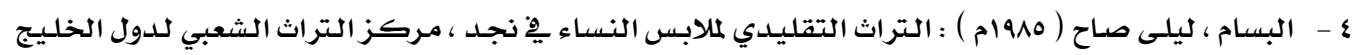

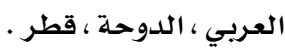

ه- البستاني ، المعلهم بطرس ( ب991م ) :القاموس المحيط باللغة العربية، مكتبة لبنان ناشرون ، لبنان .

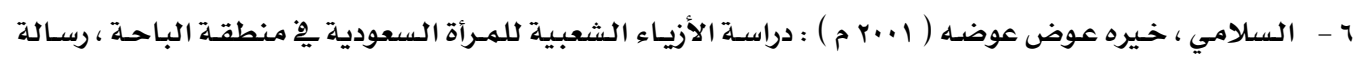

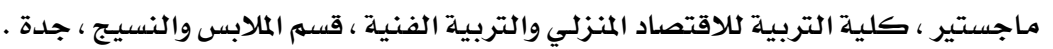

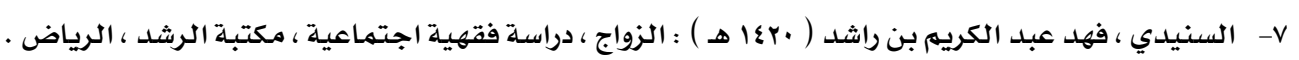

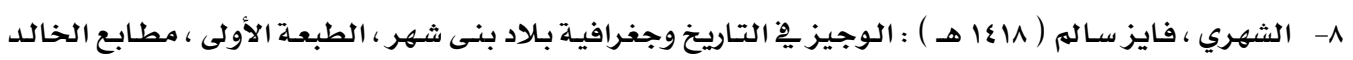

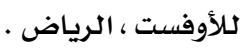

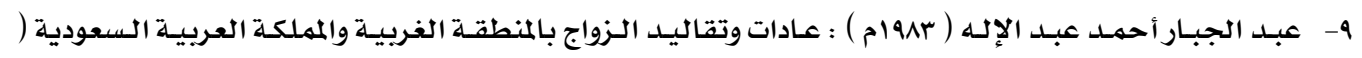

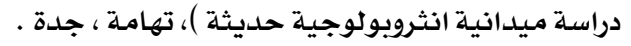

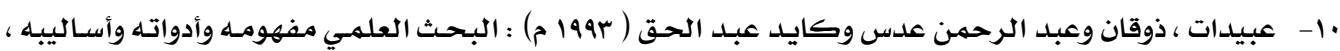

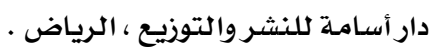

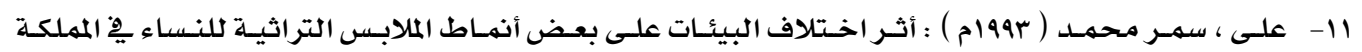

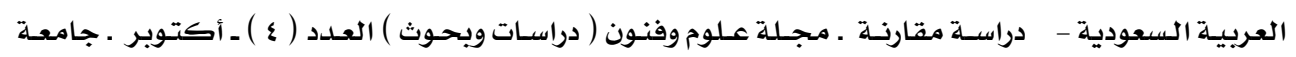
حلوان. القاهرة

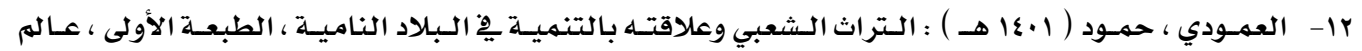

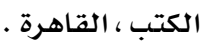

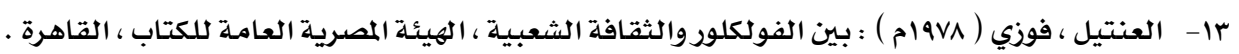

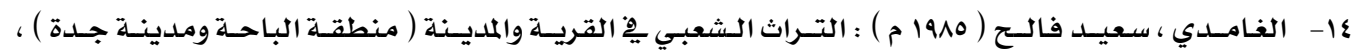

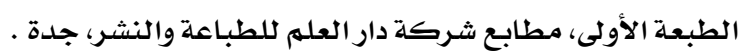

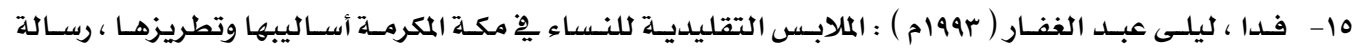

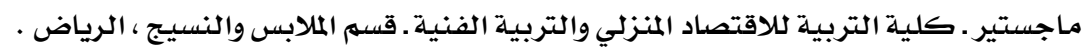

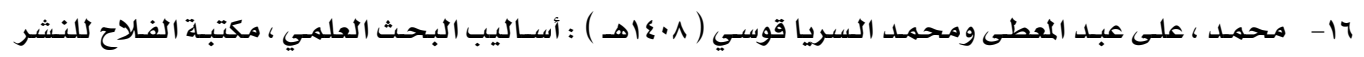

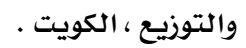

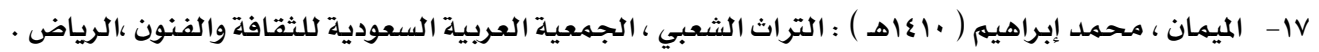

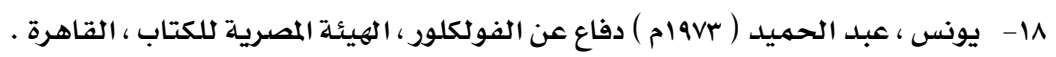


